\title{
Performance of Fungal Growth Through Integrated Gompertz Model and Respiratory Quotient by Solid State Fermentation in Multi-Layer Squared Tray Solid State Bioreactor with Aeration Strategies
}

Musaalbakri Abdul Manan ( $\sim$ bakri@mardi.gov.my )

Malaysian Agricultural Research and Development Institute (MARDI) https://orcid.org/0000-00027611-3613

Colin Webb

The University of Manchester

\section{Research Article}

Keywords: Solid state fermentation (SSF), Multi-layer squared tray solid state bioreactor (SSB), Gompertz model, Metabolic activity, Respiratory quotient (RQ)

Posted Date: June 18th, 2021

DOl: https://doi.org/10.21203/rs.3.rs-609415/v1

License: (c) (1) This work is licensed under a Creative Commons Attribution 4.0 International License.

Read Full License 
Performance of fungal growth through integrated Gompertz model and respiratory quotient by solid state fermentation in multi-layer squared tray solid state bioreactor with aeration strategies

Musaalbakri Abdul Manan ${ }^{1,2}$. Colin Webb ${ }^{2}$

1 Enzyme and Fermentation Technology Programme,

Food Science and Technology Research Centre,

Malaysian Agricultural Research and Development Institute (MARDI),

Persiaran MARDI - UPM, 43400 Serdang, Selangor Malaysia

2 School of Chemical Engineering and Analytical Science,

The University of Manchester, Oxford Road,

Manchester M13 9PL, United Kingdom

Musaalbakri Abdul Manan

bakri@mardi.gov.my

ORCID: 0000-0002-7611-3613

Colin Webb

colin.webb@manchester.ac.uk

ORCID: 0000-0002-4094-2524 


\begin{abstract}
A newly designed, laboratory-scaled and multi-layer squared tray solid state bioreactor (SSB), was developed and successfully operated in solid state fermentation (SSF) conditions. The bioreactor was divided into eight layers of squared perforated trays. Wheat bran was used as a solid substrate for the growth of Aspergillus awamori and Aspergillus oryzae. The SSB was equipped with an oxygen $\left(\mathrm{O}_{2}\right)$ /carbon dioxide $\left(\mathrm{CO}_{2}\right)$ gas analyser and a thermocouple. Continuous on-line monitoring of fungal growth could be performed by indirect methods that measure $\mathrm{O}_{2}$ consumed, production of $\mathrm{CO}_{2}$ and metabolic heat. The advantage of using this method is that there are no tedious and time-consuming sampling processes. The evolution of $\mathrm{CO}_{2}$, which represents an accumulation term, was integrated with time and fitted to the Gompertz model in a log-like equation. The Gompertz model generated values that may be used to stimulate and verify the experimental data. Results strongly suggest that the evolved and accumulated $\mathrm{CO}_{2}$, excellently described fungal growth. Simulated results agreed with experimental results. The respiratory quotient (RQ), which is the ratio of $\mathrm{CO}_{2}$ evolution rate (CER) to $\mathrm{O}_{2}$ uptake rate (OUR), was determined by the gas balance method. CER and OUR confirmed that measurements correlated to fungal activity. Each RQ values can explain the differences of each SFF process carried out. Yet, heat evolved by fungal activity also described fungal growth. The current findings is an excellent pre-liminary experimental work, evidencing that multi-layer squared tray SSB with forced moistened aeration present a promising alternative of instrumented bioreactors for SSF processes.
\end{abstract}

Key words Solid state fermentation (SSF) . Multi-layer squared tray solid state bioreactor (SSB) . Gompertz model . Metabolic activity . Respiratory quotient (RQ) 


\section{Introduction}

Solid state fermentation (SSF) has shown much promise in the development of several bioprocesses and products, with high volumetric productivity, relatively higher concentration of the products, less effluent generation, and simple fermentation equipment or bioreactor systems. Since 2000, SSF has received significant attention for the expansion of industrial bioprocesses, mainly due to its lower energy requirements and association with higher product yields, lower catabolic repression, costeffective technology and less wastewater production with a lower risk of bacterial contamination [1]. In addition, SSF can be identified as an environmentally friendly process, as it uses solid residues from agriculture industries as the source of carbon substrate.

Along with the development and modernization of technology, SSF will soon be related to a solid state bioreactor (SSB) design which is a vital development and advancement in the bioprocessing technology. A number of SSB designs exist for SSF, such as semi-continuous plug-flow [2], packed-bed [3-7], tray [8-12], trickle bed [13], multipurpose fixed-bed [14], rotating drum [9,15], horizontal drum [16], column-tray [17], novel deep-bed cubical [18], multi-layer packed-bed [19], column [20], fluidised-bed [21], hexahedral modular [22], SSF reactor (SSFR) [23], horizontal rotary drum [24], continuous counter-current [25], scrapped-drum [26], zymotis packed-bed [27], gas-solid spouted-bed [28], horizontal stirred tank [29], vertical cylindrical shaped (fed-batch SSF) [30] and cylindrical [31] bioreactors. Progress has been made in improving processes at the laboratory level, but research on bioreactor designs and process scale-ups that allow the usage of microorganisms needs further focus [32].

In any aerobic SSF processes within any type of SSB, there are a few identified factors in determining the performance of the fermentation process. They are substrates heterogeneity, water activity or moisture gradients, $\mathrm{O}_{2}$ supply, carbon dioxide $\left(\mathrm{CO}_{2}\right)$ transfer, temperature, metabolic heat removal and the bioreactor's design itself. Operational difficulties include issues related to poor $\mathrm{O}_{2}$ supply, moisture level, heat accumulation in the bioreactor system and controls, which needs to be highlighted [33]. During the fermentation process, heat is generated and can consequently and directly affect the metabolic activities of the microorganism, causing, amongst others, moisture loss. Moreover, if the temperature control and aeration fail, the selectivity of the biosynthesis process towards product formation could be lost. Additionally, there is potential for the process to fail completely. A good strategy is therefore needed to effectively remove heat from the system [34]. Moisture content, heat and evolvement of $\mathrm{CO}_{2}$ are requirements strongly linked to $\mathrm{O}_{2}$ transfer rates in aerobic processes [35-37]. Direct aeration is the principal operation that results in $\mathrm{O}_{2}$ transfer, moisture loss, heat and $\mathrm{CO}_{2}$ removal. However, these effects are increased when high biomass concentrations and microorganisms 
(particularly, filamentous fungi) are fed into the SSF, creating a complication with its use. A strategy to control these effects is to introduce forced aeration. Forced aeration allows on-line analysis of $\mathrm{CO}_{2}$ and $\mathrm{O}_{2}$ concentrations in the exhaust gas that is in accordance with and controls the fermentation process [34]. In addition, analysis of the exhaust gas has been used to indirectly estimate the biomass growth [38]. An important concept in the design of bioreactors is to allow a single vessel to have as many major operations as possible. The bioreactor is the core of the biological process with four major functions. They are: (1) to contain the substrate; (2) to contain the processed microorganism; (3) to protect the processed microorganism against contamination and (4) to control parameters and environmental conditions to optimise growth and product formation [39-41].

The most important factor need to be highlighted during microbial fermentation is sterilization. According to Sindhu et al. [42], sterilization is mandatory to strictly control bio-contaminants. This was supported by Arora et al. [33] that SSF bioreactors must be completely sealed to prevent unwanted microorganisms or harmful environmental substances from entering into the bioreactor. Besides that, temperature, $\mathrm{O}_{2}, \mathrm{CO}_{2}$ and heat removal need to be carefully controlled and optimised [39]. The SSB design must consider design and operating variables, especially aeration transfer for effective diffusion of $\mathrm{O}_{2}$ in the gas phase, effective elimination of $\mathrm{CO}_{2}$ and metabolic heat, temperature control including the cooling system $[33,34,39,43]$. In SSF, $\mathrm{O}_{2}$ transfer can often be inefficient in some designs, whereby $\mathrm{O}_{2}$ transfer is ineffectively homogenously distributed into every particle of the solid substrate. Other difficulty would furthermore affect the temperature and water content of the solid medium, thus need to be tightly and concomitantly controlled and measured [16]. Constructive bioreactors have high biological reaction rates including microbial growth performance, substrate consumption, product formation and by-product synthesis rates $[33,39,44]$. Thus, it is very important to understand which of these criteria provides the best performance for bioreactors to be constructively designed. Yet, a greater understanding of the biological systems of microorganisms and biological processes in SSF are key to improve the design of bioreactors $[32,45]$.

This work was carried out at the location where the bioreactor system was designed to generate moistened air. Here, two different arrangements were provided into the multi-layer tray SSB. The moistened air supplied water, $\mathrm{O}_{2}$ and facilitated heat and mass transfer to collectively improve fungal growth. In order to evaluate the performance of the bioreactor, final moisture content, $\mathrm{O}_{2}$ uptake rate (OUR), $\mathrm{CO}_{2}$ evolution rate (CER) and evolved temperature were investigated during fermentation. As analysis of $\mathrm{O}_{2}$ as well as $\mathrm{CO}_{2}$ in the exhaust gas is becoming generally accepted as a standard measuring technique in bioprocessing, the analysis was also applied in this study because it does not interfere with the sterile barrier. The results obtained will be discussed and reviewed for the two fungi reacting to every study design proposed. 


\section{Materials and methods}

\section{Microorganisms and sporulation medium}

The strains of Aspergillus awamori and Aspergillus oryzae were cultured and preserved in a solid sporulation medium containing 5\% (w/v) whole wheat flour and 2\% (w/v) agar (Sigma-Aldrich). The strains were activated in sterilised media and incubated over seven days at $32^{\circ} \mathrm{C}$, then preserved at $4{ }^{\circ} \mathrm{C}$. They were sub-cultured on an interval of every two months during the study.

\section{Preparation of fungal spores as inoculum}

$0.5 \mathrm{~mL}$ spore suspension was transferred onto the surface of $100.0 \mathrm{~mL}$ of the same sporulation medium in a $500.0 \mathrm{~mL}$ Erlenmeyer flask and incubated for seven days at $32^{\circ} \mathrm{C}$. After the incubation period, 50.0 $\mathrm{mL}$ of sterile $0.1 \%$ (v/v) Tween 80 solution and several sterile glass beads ( $4 \mathrm{~mm}$ diameter) were added to the flask. The spores were suspended by shaking the flask gently and then collected in a bottle as a spore suspension. Concentration of the spore suspension was measured by a haemocytometer. The volume of suspension needed for inoculation of the solid substrate was calculated for each experiment to reach a concentration of approximately $1.0 \times 10^{6} \mathrm{spores} / \mathrm{g}$ solid substrate.

\section{Preparation of wheat bran as a solid substrate and inoculum transfer procedures}

Wheat bran was obtained from the Cargill Wheat Processing Plant, Manchester, United Kingdom (UK). The substrates were kept in an airtight container and stored in a cold room $\left(4^{\circ} \mathrm{C}\right)$ for future use. Wheat bran is used without any treatment as a solid medium for growing A. awamori and A. oryzae.

Firstly, $20.0 \mathrm{~g}$ of wheat bran was weighed and placed into separate $250 \mathrm{~mL}$ flasks (in a total of eight flasks) before being sterilised at $121^{\circ} \mathrm{C}$ for $15 \mathrm{~min}$. The substrates were allowed to cool at room temperature before inoculating with A. awamori and A. oryzae spores and being moistened with an amount of sterile distilled water to obtain the initial moisture content of $65 \%$. About $1.2 \times 10^{6} \mathrm{spores} / \mathrm{g}$ substrate were inoculated into the flask and mixed well with a sterile spatula under aseptic conditions to uniformly distribute the spores within the substrate. After sufficient mixing, the content was distributed into each tray before being incubated at $32^{\circ} \mathrm{C}$ for $72 \mathrm{~h}$. At the end of the fermentation period, a sample was taken for sample analysis. 


\section{Multi-layer squared tray solid state bioreactor}

The bioreactor chamber consists of eight identical square trays perforated at the base and arranged in a stacked fashion. The enclosed assembly has a door attached to the main body of the bioreactor. The dimensions of a rectangular bioreactor assembled as one structure are $14.0 \mathrm{~cm}$ in length, $14.0 \mathrm{~cm}$ in width and $73.5 \mathrm{~cm}$ in height (Fig. 1). The main body of the bioreactor is made of aluminium while the wall at the back and the door are made of the Perspex material. The enclosing structure of the bioreactor is of a durable transparent material, thereby enabling viewing of the bioreactor chamber contained therein. In one structure, the dimensions of the tray are of $12.0 \mathrm{~cm}$ in length, $12.0 \mathrm{~cm}$ in width and 2.0 $\mathrm{cm}$ in height. The tray was constructed from the Perspex material and equipped with a perforated base with an aperture size of $150 \mu \mathrm{m}$ that permits operation, sterilization and high conduction.

The bioreactor chamber's assembly was configured as a module that fits in an autoclave. The bioreactor was autoclaved for $15 \mathrm{~min}$ at $121^{\circ} \mathrm{C}$ prior to operation. After cooling to room temperature, the reactor was filled with sterile inoculated substrate in a laminar flow cabinet under sterile conditions. Each tray can hold up to about $20.0 \mathrm{~g}$ of solid substrate with a $1.5 \mathrm{~cm}$ bed height. The tray medium enters the bioreactor chamber through the door. The door is then sealed to avoid any access from the environment into the system and vice versa. Each subsequent tray was assumed to be filled in the same thus are all under equal conditions. A schematic diagram of the experimental set-up consisting of the multi-layer tray SSB with aeration, control and on-line monitoring system is shown in Fig. 2.

\section{Bioreactor setup and fermentation experiments}

The bioreactor and solid substrate were autoclaved separately at $121^{\circ} \mathrm{C}$ for $15 \mathrm{~min}$, prior to operation. The sterilised substrate was inoculated with $1.2 \times 10^{6}$ spores/g substrate in another Erlenmeyer flask before loading into the sterile tray and before transfer into the bioreactor. All work was carried out in a laminar flow cabinet under sterile conditions. The bioreactor was then placed in an incubator room for $72 \mathrm{~h}$ at $32^{\circ} \mathrm{C}$. Sterile moistened air was introduced as a fluidising medium at the bottom of and on the surface of the tray from the compressor depending on the air strategies applied to every experiment. Two air flow rates were chosen as moistened air is sparged in two arrangements. Firstly, sterilised moistened air at a flow rate of $8 \mathrm{~L} / \mathrm{min}$ was passed into an air distributor at the bottom of the bioreactor before being forced through the perforated mesh tray from bottom to the top (labelled as Exp 1). Secondly, sterilised moistened air at a flow rate of $1 \mathrm{~L} / \mathrm{min}$ was passed onto the surface of each fermented substrate (labelled as Exp 2). These air arrangements are described in Table 1. For moistened air, dry air from the compressor (Air compressor JUN-AIR, USA) was passed through a humidifier chamber before entering the system. The flow rate of the air into the bioreactor system was accurately measured and adjusted with a rotameter. The air was sterilised by passing it through a $0.45 \mu \mathrm{m}$ cellulose 
acetate membrane filter and then into a humidifier chamber with sterilised distilled water which was monitored in a water bath at $30^{\circ} \mathrm{C}$.

\section{Measuring metabolic activity during solid state fermentation}

\section{Online monitoring of temperature}

Each tray was equipped with a thermocouple type K (Pico Lab Technology, UK) placed at the surface of the fermented substrate to continuously record the bed temperature over time. All of the on-line data were monitored on screen and recorded using a computer.

\section{Online monitoring of respiratory gases}

The system used for quantifying $\mathrm{O}_{2}$ and $\mathrm{CO}_{2}$ continuously measured exhaust gas compositions online. An air outlet was situated in the headspace of the highest tray. The exit gas may need to be conditioned (moisture removed) before venting into the gas analyser. Therefore, the humid exhaust air from the bioreactor was firstly dried by passing through silica gel-containing tubes before entering an $\mathrm{O}_{2} / \mathrm{CO}_{2}$ analyser (FerMac 368 Electrolab, UK). This analyzer was connected to the Electrolab eLogger data logging and translates the concentration of $\mathrm{O}_{2}$ and $\mathrm{CO}_{2}$ to be recorded using a computer system.

\section{Mathematical modelling}

\section{Quantification of oxygen uptake and carbon dioxide evolution rates}

In this study, $\mathrm{O}_{2}$ uptake rate (OUR) and $\mathrm{CO}_{2}$ evolution rate (CER) were calculated using the following equations [46].

$\mathrm{O}_{2}$ uptake rate (OUR):

$$
\text { OUR }=\frac{F_{1}}{V_{m} \times V_{0}}\left(X_{O_{2}(\text { in })}-\frac{1-\left(X_{O_{2}(\text { in })}+X_{C_{2}(\text { in })}\right)}{1-\left(X_{O_{2}(o u t)}+X_{C_{2}(o u t)}\right)} \times X_{O_{2}(\text { out })}\right)
$$

$\mathrm{CO}_{2}$ evolution rate (CER):

$$
C E R=\frac{F_{1}}{V_{m} \times V_{0}}\left(X_{\mathrm{CO}_{2}(\text { out })} \times \frac{1-\left(X_{\mathrm{O}_{2}(\text { in })}+X_{\mathrm{CO}_{2}(\text { in })}\right)}{1-\left(X_{O_{2}(\text { out })}+X_{\mathrm{CO}_{2}(\text { out })}\right)}-X_{\mathrm{CO}_{2}(\text { in })}\right)
$$


Where;

$\begin{array}{ll}\text { OUR } & : \mathrm{O}_{2} \text { uptake rate (mole/L.h) } \\ \text { CER } & : \mathrm{CO}_{2} \text { evolution rate (mole/L.h) } \\ F_{1} & : \text { Air flow rate of inlet gas }(\mathrm{L} / \mathrm{h}) \text { at } 1 \text { atm and } 30^{\circ} \mathrm{C} \\ V_{m} & : \text { Molar volume of gases }=24.88 \mathrm{~L} / \mathrm{mole} \text { at } 1 \mathrm{~atm} \text { and } 30^{\circ} \mathrm{C} \\ V_{0} & : \text { Working volume, solid phase }(\mathrm{L}) \\ X_{O_{2(\text { in })}} & : \text { Molar fraction of } \mathrm{O}_{2} \text { at gas inlet } \\ X_{O_{2(\text { out })}} & : \text { Molar fraction of } \mathrm{O}_{2} \text { at gas outlet } \\ X_{C_{2(\text { in })}} & : \text { Molar fraction of } \mathrm{CO}_{2} \text { at gas inlet } \\ X_{C_{2(\text { out })}} & : \text { Molar fraction of } \mathrm{CO}_{2} \text { at gas outlet }\end{array}$

This equation is based on the inert gas balance. It is assumed that $\mathrm{CO}_{2}$ is the only gaseous product of the fermentation process [46].

\section{The Gompertz curve as a fungal growth curve}

The Gompertz model was first initiated by Benjamin Gompertz (1825) and a thorough analysis of the model has been described by Winsor, (1932). The Gompertz model is a sigmoid function of the logistic curve and has been used as a growth curve, both for biological and economic phenomena [47]. An improvement to the model and derivation based on the systems theory was done by Skiadas and Skiadas [48]. In differential equation form, the model is based on this equation:

$$
(\ln x)^{\prime}=-b \ln x
$$

Where;

$x=$ the function of time

$b=$ a positive constant expressing the rate of growth of the system

Without loss of generality, the function of $x$ can be assumed bounded $(0<x<1$, with $x=1$ corresponding to the entire population), in order that $x$ is the probability density's function of the growth process. Direct integration of equation 3 gives a solution to the Gompertz function [48]:

$$
x=\exp \left(\ln \left(x_{o}\right) \exp (-b t)\right)
$$

The integrated Gompertz model, was used to analyze the kinetic data [49-51]. In this logistics-like model, the product $\left(\left[\mathrm{CO}_{2}\right]\right)$ is a function of time $(t)$ according to the following equation. 


$$
\left[\mathrm{CO}_{2}\right]=\left[\mathrm{CO}_{2_{\max }}\right] \exp (-b \exp [-k t])
$$

Where;

$$
\begin{array}{ll}
{\left[\mathrm{CO}_{2_{\text {max }}}\right]} & : \text { the maximum } \mathrm{CO}_{2} \text { concentration }(\text { at } \mathrm{t} \text {----------> } \infty)(\text { mole) } \\
b & : \text { a constant related to the initial conditions (when } t=0, \text { then } \\
& {[\mathrm{CO} 2]=\left[\mathrm{CO}_{2_{0}}\right]=\left[\mathrm{CO}_{2_{\text {max }}}\right] \exp (-b)(\text { dimensionless) }} \\
k & : \text { the specific } \mathrm{CO}_{2} \text { evolution rate }\left(\mathrm{h}^{-1}\right) \\
t & : \text { fermentation time }(\mathrm{h})
\end{array}
$$

The constants $\left[\mathrm{CO}_{2 \text { max }}\right], b$ and $k$ were estimated from the data using a non-linear regression programme. The value of $k\left(\mathrm{~h}^{-1}\right)$ refers to the time it takes for the value of $\left[\mathrm{CO}_{2}\right]$ to reach $\left[\mathrm{CO}_{2_{\max }}\right]$. Larger values of $k$ cause $\left[\mathrm{CO}_{2}\right]$ to reach $\left[\mathrm{CO}_{2}\right.$ max $]$ in a shorter time. The value of $b$ (dimensionless) will determine the shape of the sigmoidal curve. Larger values of $b$ cause the initial exponential growth phase to be slower and the deceleration phase to reach asymptote faster. Smaller values of $b$ cause a rapid exponential growth phase and slower deceleration before the asymptote of $\left[\mathrm{CO}_{2}\right]$ is reached [47]. Here, asymptote refers to a line that continually approaches a given curve but does not meet it in any finite distance.

\section{Gas balance and calculation of respiratory quotient}

The respiratory quotient (RQ) can be directly calculated when the composition of the exhaust gas is known according to the following equation:

$$
R Q=\frac{C E R}{O U R}
$$

Where;

$$
\begin{array}{ll}
R Q & : \text { Respiratory quotient (dimensionless) } \\
C E R & : \mathrm{CO}_{2} \text { evolution rate }\left(\text { mole } \mathrm{L}^{-1} \mathrm{~h}^{-1}\right) \\
\text { OUR } & : \mathrm{O}_{2} \text { uptake rate }\left(\text { mole } \mathrm{L}^{-1} \mathrm{~h}^{-1}\right)
\end{array}
$$

\section{Determination of final moisture content}

The moisture content of the samples was determined using the oven method, by measuring weight loss after heating to a constant weight at $95^{\circ} \mathrm{C}$. Samples were placed in pre-dried metallic dishes with a 
known weight and immediately weighed. After being dried in the oven for $24 \mathrm{~h}$, the samples were cooled for $30 \mathrm{~min}$ in desiccators before a final weighing.

\section{Enzyme extraction and activity determination}

After the $72 \mathrm{~h}$ fermentation period, samples were taken for enzyme (glucoamylase, protease, xylanase and cellulase) analysis. Fermented samples (2.0 g on a wet basis) were extracted with distilled water $(40.0 \mathrm{~mL})$ and agitated for $30 \mathrm{~min}$ on a rotary shaker (Infors A - CH 4103 Switzerland) at $250 \mathrm{rpm}$ and $30{ }^{\circ} \mathrm{C}$. Next, the solid suspensions were centrifuged at $10,000 \mathrm{rpm}$ for $10 \mathrm{~min}\left(4^{\circ} \mathrm{C}\right)$. The clear supernatant was used for enzyme analysis. Glucoamylase was assayed using a method as described by Ariff and Webb [52], using maltose as a substrate. Protease activity was measured using the ninhydrin colourimetric method as outlined by the European Brewery Convention with modifications made by Wang [53]. Determination of xylanase activity was conducted according to a method developed by Bailey et al. [54], while filter paper-based cellulase activity was measured according to IUPAC recommendations [55]. Here, filter paper Whatman No. 1 was employed as a substrate [56]. A standard operational procedure for enzymes analysis was developed in this study, as reported elsewhere [57].

\section{Spore's count}

About $2.0 \mathrm{~g}$ (wet weight) of fermented substrate of A. awamori and A. oryzae were used to harvest the spores in a $250 \mathrm{~mL}$ flask containing $40 \mathrm{~mL} 0.1 \%(\mathrm{v} / \mathrm{v})$ Tween 80 . The flasks were continuously agitated in an orbital shaker at $100 \mathrm{rpm}$ for $30 \mathrm{~min}$ at $30^{\circ} \mathrm{C}$. The spore suspensions were then filtered using a stainless-steel sieve with an aperture size $45 \mu \mathrm{m}$ to separate the solid particles. Spores were counted using a haemocytometer.

\section{Results and Discussion}

\section{Effect of air arrangements on final moisture content during fungal growth}

Fig. 3 shows profiles of the average and final moisture content from multi-layer tray SSB. Fermented A. awamori in Exp 1[AA] experienced high loss of moisture content for every tray (ranging between 51.95 to 59.82\%). For fermented A. awamori in Exp 2[AA], the moisture content loss was not as critical as in Exp 1[AA] (ranging between 59.8 to $62.22 \%$ ). However, the final moisture content for fermented A. oryzae was above the initial level of $65 \%$. Exp 1[AO] recorded a final moisture content within the range of 66.04 to $67.84 \%$, while in $\operatorname{Exp} 2[\mathrm{AO}$, the final moisture content was in between 66.71 and $69.89 \%$ for all the eight trays. A. oryzae proved to have high ability to retain water in its cells compared 
to A. awamori, as previously reported [58]. Thus, in combination, wheat bran and A. oryzae were able to retain water and resulted in a high final moisture content in the fermented A. oryzae product.

This system was completely sealed with no access to the air from the inside or outside. However, large gas spaces in between the trays were included. In Exp 2[AA] and Exp 2[AO]air sparged directly onto the surface of the fermented substrate provided advantages to the trays above. For example, substrate in the tray at position 2 has access to air from: (i) the surface itself and (ii) the bottom of the perforated tray on which the air was sparged. The tray at position 3 has the same advantage as the tray at position 2. It seemed that trays at positions $2,3,4,5,6,7$ and 8 were aerated both from the surface and the bottom. Only the tray at position 1 was aerated from the surface.

There are some key factors affecting the moisture content in SSF and it is important to know their influence on the processes. It could be summarised that A. awamori and A. oryzae were very versatile but also a sensitive type of fungi towards air arrangement in bioreactor systems. The use of moistened air as an alternative to provide adequate $\mathrm{O}_{2}$, is suitable for moisture content control. The air flow through the fermented substrate was also observed to play an important role in carrying moisture from the fermented substrate. When air was forced from the bottom to the top, it had a negative effect on $A$. awamori culture but a positive effect on A. oryzae. When air was blown through the surface of the fermented substrate, it had a negative effect on the moisture content for both fungi. However, this is not the only factor to determine high productivity of the culture. At the initial fermentation stage, the temperature, $\mathrm{O}_{2}$ and moisture content are expected to be the same throughout the SSF system; however, as the fermentation progresses, $\mathrm{O}_{2}$ is consumed, heat is evolved and water is evaporated, and therefore gradients of temperature, moisture, gas, substrate and products are commonly observed in the fermented bed [14].

\section{Gompertz curve and analysis of a distributed gas balance during fungal growth}

Fig. 4[a] shows the profile of $\mathrm{CO}_{2}$ evolved during the fermentation process for both fungi. Fig. 4 [b] shows the fitting of the Gompertz model to these data for both fungi during SSF with wheat bran for the description of fungal growth. In this system, it is clear that air arrangement has a direct influence on the metabolic activity and evolved $\mathrm{CO}_{2}$. The strategy to supply air onto the surface of the fermented substrate $(\operatorname{Exp} 2)$ with moistened air at a flow rate of $1 \mathrm{~L} /$ min greatly enhanced the evolution of $\mathrm{CO}_{2}$ compared to Exp 1.

For Exp 2 (for both A. awamori and A. oryzae), the evolution of $\mathrm{CO}_{2}$ was higher probably due to high concentration of $\mathrm{O}_{2}$ at the surface of fermented substrate. With a low flow rate at $1 \mathrm{~L} / \mathrm{min}$, the accumulation of $\mathrm{O}_{2}$ in the headspace (between the trays) was adequate to supply $\mathrm{O}_{2}$ for the fungi. 
Compared to Exp 1, the concentration of $\mathrm{O}_{2}$ might be variable in different locations of the trays. The bottom tray might have a higher concentration of $\mathrm{O}_{2}$ compared to the trays above. Another probable reason for these differences is that some amount of $\mathrm{O}_{2}$ might have escaped from the system due to the built-up of high pressure. The high pressure may be a result of the high flow rate used, at $8 \mathrm{~L} / \mathrm{min}$ in Exp 1.

The kinetics constants are presented in Table 2. The model was found to be adequate to describe the integrated data from $\mathrm{CO}_{2}$ evolution, as seen from the $\mathrm{R}^{2}$ coefficients $\left(\mathrm{R}^{2}>0.997\right)$. The arrangement of trays with air sparged onto the surface of fermented substrate (Exp 2) greatly enhanced $\left[\mathrm{CO}_{2_{\text {max }}}\right]$ (by more than 2-fold) compared to Exp 1 for both fungi. This was expected since in this system there are eight trays with the same amount of solid substrate.

The evolution rate $(k)$ values were 0.048 and $0.059 \mathrm{~h}^{-1}$ for A. awamori and A. oryzae, respectively (Exp 2). Yet, there is no clear relationship between this parameter and the amount of $\mathrm{CO}_{2}$ produced, as characterised by $\left[\mathrm{CO}_{2_{\max }}\right]$ from all experiments. Another parameter, the $t_{\max }$ value, coincided with those obtained for the maximum evolution of $\mathrm{CO}_{2}$ and in most cases correspond to those experimentally obtained.

Further, the experimental data for the cumulative evolved $\mathrm{CO}_{2}$ by A. awamori and A. oryzae was calculated using the Gompertz model. The Gompertz model showed an excellent agreement between experimental and predicted data in growth rate for A. awamori and A. oryzae, with an $\mathrm{R}^{2}>0.99$ (Fig. $4[\mathrm{c}])$. It was observed that fitting the growth models to the accumulated $\mathrm{CO}_{2}$ evolution raw data was meaningful and more feasible for further analysis. Data of the $\mathrm{CO}_{2}$ evolution were easy to interpret with this model. It was observed that the concentration of $\mathrm{CO}_{2}$ increases during SSF over time, following a sigmoidal curve that describes fungal growth (Fig. 4 [a] and $4[\mathrm{~b}]$ ). The variation in the patterns of the sigmoidal curve were produced in response to two different moistened air arrangements. Yet, from all experiments on $\mathrm{CO}_{2}$ evolution, the evaluated parameters revealed that the total amount of $\left[\mathrm{CO}_{2_{\text {max }}}\right]$ was dependent on the type of fungus and air arrangement. It is perceived that in all the cases in this study, it was practicable to use the Gompertz model to describe fungal growth in SSF based on the $\mathrm{CO}_{2}$ evolution. Thus, this model allowed an excellent prediction of the effects of moistened air arrangement on $\mathrm{CO}_{2}$ evolution during SSF. In this study, it can be summarised that the Gompertz model is the best to describe the growth curves of A. awamori and A. oryzae. Here, the growth A.awamori and A. oryzae in every experiment, followed a typical pattern with four distinct phases: (i) a lag phase, (ii) an acceleration phase, (iii) a log (exponential) phase and (iv) a deceleration phase. Yet, there was no clear stationary phase and no accelerated death phase observed. 
Ultimately, given the assumptions to be considered, the Gompertz model shows potential. It has the ability to describe the varied outcomes under different culture conditions. Previously, the Gompertz model proved most suitable to fit the experimental data in a kinetic study on anaerobic treatment of a hazardous steel-mill waste known as rolling oil [59]. The biomass data obtained from the growth analysis of Streptomyces venezuelae for the effect of ultrasonication was well fitted to the Gompertz model [60]. Additionally, the Gompertz model predicted the microbial inactivation under varying time and temperature subjected to the surface of a food product. Here, the model required non-linear regression schemes and analyses were tested on pseudo-experimental data [61]. According to Kafle et al. [62], the modified Gompertz model fitted the experimental data better than a first-order kinetic model, during anaerobic treatment of apple waste with swine manure for biogas production. In addition, the modified Gompertz model best described the growth of Pseudomonas in raw pork under pallet packaging at all temperature conditions [63]. According to Augustine et al. [64], the Gompertz model does not incorporate the symmetry restriction, has a shorter period of fast growth and gave the best fit for growth kinetic study of filamentous fungi in SSF.

Based on simulation work by Mitchell et al. [65], a relevant approach to modelling the product formation kinetics in SSF is valuable, owing to the difficulty in monitoring the different variables involved in the fermentation systems. Christen et al. [51] used the Gompertz model to describe the growth of Ceratocystis fimbriata in SSF and reported that the integrated data of $\mathrm{CO}_{2}$ and volatile compounds production curve gives a good fit. Soares et al. [66] used the Gompertz model to observe the growth of $C$. fimbriata to describe the total volatile compounds production during SSF on coffee husks. Whilst, Erkmen [67] used the Gompertz model to describe the growth in Listeria monocytogenes, aerobic bacteria and lactic acid bacteria, during ripening and storage process. Other researchers used the Gompertz model of growth curve to describe the time course of fermentation under different conditions for lipopeptide production by Bacillus amyloliquefaciens in SSF [68]. Braissant et al. [69] suggested the use of the Gompertz model as a growth model and potential application to microcalorimetric data. Their study further observed the use of microcalorimetry in microbiology and biology, thus has become available to the end users of isothermal microcalorimetry. Instead of SSF, Augustine et al. [64] reported that the Gompertz model can be used to describe the growth of bacteria and yeasts in liquid media. Yet, the Gompertz and other log model possess similar properties that make them useful for the empirical representation of growth [47].

\section{Metabolic measurements during fungal growth}

\section{Quatification of OUR and CER to describe fungal growth}


It is possible to estimate biomass development in SSF by considering OUR and CER, which are easily measurable parameters. OUR and and CER offer the advantage of a fast response time and are directly linked to the metabolism of the microorganism [38,70]. Fig. 5 shows OUR and CER profiles from four experiments carried out for both fungi.

The stationary growth phase for both fungi in all tray SSB systems were clearly reflected in the OUR and CER evolved heat curves. This growth phase was very short and lasted for 1 to $2 \mathrm{~h}$ of the fermentation time. The curves were not of a sigmoidal shape and reached the maximum value of $\mathrm{O}_{2}$ consumption, $\mathrm{CO}_{2}$ generation and heat evolution approximately in between 24 to $30 \mathrm{~h}$ of fermentation. After this peak, the gradual decrease of heat and $\mathrm{O}_{2}$ and $\mathrm{CO}_{2}$ concentrations indicated the beginning of the last phase, which corresponds to slower fungal growth. This is a very slow phase of progress because the active spores still consume the $\mathrm{O}_{2}$ (plus other nutrients) and produce $\mathrm{CO}_{2}$ and heat. During the SSF of Rhizopus oligosporus with rice bran as the substrate, similarly, an increase in OUR and evolved heat at around $24 \mathrm{~h}$ of fermentation followed by a significance decrease was reported at $72 \mathrm{~h} \mathrm{[71].} \mathrm{In} \mathrm{this}$ scenario, it was considered that the high content of readily available starch, as a carbon source in wheat bran, was the reason for the comparatively high OUR, CER and evolved heat. This indicated high fungal growth during the first 24 to $30 \mathrm{~h}$ of SSF. Furthermore, in SSF, fungi cannot grow continuously as the amount of nutrients available is finite and waste products will accumulate. These conditions might be the reason for the deceleration of fungal growth after achieving maximum activity. Growth still continues but at a slower due to thepresence of nutrients.

\section{Heat evolution as a mechanism to describe fungal growth}

Temperature is the limiting design consideration for most SSB systems. A high amount of metabolic heat is produced during growth. The temperature of SSF cultures often increases to levels incompatible with growth. As the scale of SSB increases, the mechanism of heat transfer rapidly becomes insufficient. The forced addition of air is usually necessary to allow evaporative cooling of the fermented substrate and also the system. Some form of moisture control is then required. Forced aeration with saturated moistened air can then be introduced into the system.

The effects of moistened air with two arrangements in multi-layer tray SSB are shown in Fig. 6. Fungal growth for both fungi with Exp 2 provided a great respond based on temperature profiles during the 72 $\mathrm{h}$ of fermentation time. The temperature reached maximum at about $27 \mathrm{~h}$ with 37.03 and $36.55{ }^{\circ} \mathrm{C}$ for A. awamori and A. oryzae, respectively. All experiments show a rise in temperature after $18 \mathrm{~h}$ of fermentation, reaching a maximum between 27 and $30 \mathrm{~h}$ before it started to decrease until the end of the fermentation. Exp 2 with the moistened air at a flow rate of $1 \mathrm{~L} / \mathrm{min}$ tended to be suitable for growth conditions, and for both fungi, the temperature recorded to be below $40{ }^{\circ} \mathrm{C}$. Exp 1 with a flow rate of 8 
L/min successfully witnessed the movement of generated heat from each tray, from the bottom to the top due to the high flow rate.

A better growth performance was observed in Exp 2 due to adequate $\mathrm{O}_{2}$ concentration. Furthermore, in Exp 2, the air was not forcefully blown through the bed but rather circulated through the headspace above the bed. Additionally, the substrate in the perforated mesh tray allowed better air circulation around the trays. Perforation in a tray's base allows air flow through the tray to assure uniform mass and heat transfer. The system was properly sealed with a gap of about $2.0 \mathrm{~cm}$ between the trays to allow better aeration and $\mathrm{O}_{2}$ accumulation.

In the current tray system of bioreactors, it was impossible to maintain the bed temperatures at the optimum value for growth, and therefore the fungus will suffer variations in temperature during the fermentation process. It is worth mentioning that from these studies, the amount of water loss and drying of the substrate were not drastic. Another important factor is the ability of the fungus to deal with fermentation conditions. For example, in this study, A. awamori might have suffered higher water loss compared to A. oryzae. However, the growth of A. awamori tended to be excellent in all experiments. At the same time, inhibitory metabolites were increasing due to waste accumulation within the system. The temperature often reaches values which severely limit growth or even kill the microorganims $[8,19,65,70,71]$. High temperatures might affect spore germination and growth, and product formation. This can be observed in temperature profiles illustrated in Fig. 6 where a temperature of above $30^{\circ} \mathrm{C}$ were noted in all experiments.

The approach taken by creating moistened air flow in the system created a cooling system able to supply moisture into the fermentation substrate. At one stage, the substrate possessed enough moisture to support growth and fungal metabolic activities. The growth rate was expressed solely as a function of the current temperature according to the experimental results. The increment of temperature during SSF in the tray and the insulated packed-bed bioreactors was responsible for changes in the use of the soybean oil and in protease secretion by Yarrowia lipolytica [8]. A strategy that uses intermittent trickling of water in the bed bioreactor, results in good temperature control, avoiding the bed from drying, preventing substrate compaction, as well as increased Aspergillus ficuum mycelium growth and phytase production [13]. Evaluation of different airflow distribution techniques in a pilot-scale bioreactor by using an inner tube for air supply resulted in more homogenous enzyme production, with higher activities by the fungus, Myceliophthora thermophila I-1D3b [4].

Additionally, temperature can be expressed as a function of the evolved $\mathrm{CO}_{2}$ in the system. The profile for both parameters recorded in this work can almost provide an adequate estimation of the complete growth curve including the lag, log, exponential, and stationary growth phases. However, this profile 
cannot provide a complete representation that also includes the death phase. Instead, it clearly shows that the growth becomes slower after the exponential phase, as reported by Finkler et al. [72] on their investigation of heat and mass transfer done in the absence of growth. Furthermore, research on hydrodynamics under abiotic and biotic conditions in a novel bench-scaled wall-cooled tray SSB packed with moistened particles of agro-industrial waste, provided a focused understanding of the interaction with heat and mass transport mechanisms [73].

\section{Respiration quotient and considerations about fungal growth}

RQ simply explains the state of the microbial population in the fermentation process and gives an indication of the behaviour of metabolic activity. Accurate measurements of $\mathrm{CO}_{2}$ and $\mathrm{O}_{2}$, allow precise and instantaneous estimation of kinetic parameters associated with the respiration of the culture such as the specific OUR, CER and the RQ [38]. According to Equation 7, a theoretical RQ of the oxidation of simple sugars for aerobic microorganisms is equal to $1[74,75]$.

$$
\text { Sugars }\left(\mathrm{C}_{6} \mathrm{H}_{12} \mathrm{O}_{6}\right)+6 \mathrm{O}_{2} \rightarrow 6 \mathrm{CO}_{2}+6 \mathrm{H}_{2} \mathrm{O}
$$

The equation shows that during glucose fermentation through aerobic fermentation, the rate of $\mathrm{O}_{2}$ consumption is ideally six molecules, while six molecules of $\mathrm{CO}_{2}$ are produced per glucose molecule $[74,75]$. These deliberations are based on simple sugars, or related carbohydrates or polysaccharides [75]. It is important to know that solid substrate used in SSF has varying nutrients composition of carbon and nitrogen. Some contain complex compositions such as hemicellulose, cellulose and lignin. In this situation, microorganisms need to utilise the entire complex of the compounds and produce simple fermentative sugars before these can be easily consumed. In the practical terms in SSF, it is impossible to obtain the RQ equal to 1 , but the probability of obtaining RQ $<1$ and $R Q>1$ is possible as shown in Equation 8.

When $\mathrm{RQ}<1$, it is assumed that one or more non-constitutive or newly induced metabolites have been possibly produced. $\mathrm{CO}_{2}$ was not the only product produced during the microbial fermentation. According to Equation 8, other products, such as energy (ATP), water and secondary metabolites were produced. Yet, $\mathrm{O}_{2}$ is not only used for the respiration process but also for cell maintenance [74,75].

$$
\text { Organic material }+\mathrm{nO}_{2} \rightarrow \text { Biomass }+ \text { sugars }+n \mathrm{CO}_{2}+\mathrm{nH}_{2} \mathrm{O}+\text { Energy }
$$

$\mathrm{RQ}>1$ indicates low $\mathrm{O}_{2}$ uptake and the occurrence of glucose fermentation. It is also indicates anaerobic fermentation. For example, in highly aerated fermentation, it is often considered that higher 
concentration of $\mathrm{O}_{2}$ was washed out, corresponds to badly functioning aeration and the existence of anaerobic zones in the fermenter system that must be immediately resolved $[38,74,75]$.

Further discovery of off-gas analysis is provided in this work for multi-layer squared tray SSB with two varied air arrangements. The rates of $\mathrm{O}_{2}$ consumption and $\mathrm{CO}_{2}$ evolution are presented along with the calculated RQ values, giving further insights into the behaviour of the fermentation process. Fig. 7[a] shows the profiles of RQ obtained using Equation 6 for both fungi in multi-layer squared tray SSB with moistened air arrangements. The RQ values are presented in Fig. 7[b]. These RQ values were generated by obtaining the slope from every experiment illustrated in Fig. 7[a]. It was observed in these studies that all RQ values obtained were below 1 (Fig. 7[b]). Exp 1, the RQ value was 0.533 and 0.578 for $A$. awamori and A. oryzae, respectively. Whilst, RQ values were higher in Exp 2. With the air arrangement in Exp 2, the RQ value for A. awamori and A. oryzae was 0.947 and 0.868 , respectively. A. awamori showed RQ values around 1 . The gas phase between the trays and the blowing of moistened air at 1 $\mathrm{L} / \mathrm{min}$ onto the fermented surface provided a higher advantage for fungal growth. It was assumed that adequate $\mathrm{O}_{2}$ concentration was available in the system. This situation arises because of the perforations at the bottom of the trays, that facilitate mass transfer to the gaseous surrounding, both at the top and the bottom.

In SSF, the mycelium growth of fungi is restricted by the diffusion of $\mathrm{O}_{2}$ in the fermented solid substrate, especially in the inner depth [3]. Poor growth might occur deep within because $\mathrm{O}_{2}$ transfer inside the solid substrate is blocked due to the compact structure of the solid particles [3]. These situations were observed in rice koji at high moisture contents. Here, poor growth of the deeply submerged mycelium was probably caused by blocked $\mathrm{O}_{2}$ flow inside the rice grains [76]. The same observation was noted during the growth of A. niger in a tray SSF system that was limited by heat and $\mathrm{O}_{2}$ transfer, with the bed height of a tray reactor being limited due to heat, had mass transfer limitations and the presence of heat transfer gradients [77]. The study suggested that by increasing the thickness of the fungal biofilm around the solid particles, the porosity of the substrate bed and diffusivity of $\mathrm{O}_{2}$ in the bed were reduced.

According to Govind et al. [78], RQ values are close to 1 until $\mathrm{O}_{2}$ uptake reaches a maximum level and thereafter RQ becomes higher than 1 due to utilisation of metabolite products. Becerra and GonzalezSiso [79] argued that changes in RQ values could be associated with the production of multiple products by Streptomyces cattleya during SSF. Barrios-Gonzalez et al. [80] reported that RQ of 0.7 obtained from their work indicated oil-supported metabolism for Nocardia lactamdurans during the production of efrotomycin in SSF. As recommended practise based on a simulation work by Rodríguez-León et al. [75], RQ patterns indicated the kind of kinetics involved in a particular fermentation process influenced by metabolite productions and microbial growth that can be categorized as (1) associated growth (RQ value close to 1); (2) partially associated growth (RQ value lower than 1 in the case the substrates are 
polysaccharides from simple sugars units) and (3) non-associated growth (RQ value lower than 1 in the case sugar or related molecules are the substrate) [75]. Overall, the RQ values must be determined for particular processes and conditions [38].

\section{The correlation between $R Q$ and production of $\mathrm{CO}_{2}$ during fungal growth}

Fig. 8 shows exponential regression analysis of the relationship between $\left[\mathrm{CO}_{2_{\max }}\right]$ and RQ, giving a straight line $\left(\mathrm{R}^{2}>0.9\right)$ for both fungi, using data from 4 experiments. It should be noted that, changes in RQ value can be correlated with changes in the metabolic condition of the fungus. Based on the results, it was assumed that A. awamori and A. oryzae apparently adapted to aeration strategy, complete oxidation (microbial respiration) and utilisation of the available nutrients provided in the system (water, $\mathrm{O}_{2}$ etc.). In this proposed concept, $\mathrm{O}_{2}$ is continuously supplied to ensure a homogenously into solid substrate and RQ has proven to be an effective indicator for the measurement of metabolic conditions in SSF processes. RQ input associated with $\mathrm{CO}_{2}$ evolved during fungal growth and biomass accumulation phases should be used throughout the development of the fermentation conditions. The RQ values of the metabolic activity may have resulted from beneficial microbial respiration by $\mathrm{O}_{2}$ consumption and $\mathrm{CO}_{2}$ evolution rate $[38,75]$. Thus, it would be convenient for a basic laboratory SSF bioreactor to have a gas analysis system at the bioreactor's outlet. A simulation work by Mann et al. [81], described the calculation of the ratio of evolved $\mathrm{CO}_{2}$ similar to the RQ for aerobic fermentation, allows the prediction of whether acetate or ethanol is predominantly produced during syngas fermentation in quasi-continuously ventilated shake flasks using Clostridium ljungdahlii. Different types of solid substrates, microorganisms, SFF bioreactor systems and the overall metabolic pathway must be taken into account to obtain a proper RQ value [34,74,75]. Mendez-Gonzalez et al. [34] reported that conidia production and productivity were significantly enhanced with packed bed column with forced aeration compared to tray and plastic bag bioreactors. Forced aeration allowed online measurement of $\mathrm{CO}_{2}$ production and proved to have an important role in determining when to harvest conidia from Metarhizium robertsii in SSF processes.

\section{The correlation between heat evolution with CER during fungal growth}

One of the most remarkable observational findings was the strong correspondence between the increase of temperature and the concentration of evolved $\mathrm{CO}_{2}$ during the $72 \mathrm{~h}$ fermentation. A high degree of correlation was found to relate the evolving $\mathrm{CO}_{2}$ and metabolic heat, as a result of carbon utilization. During the period of $\mathrm{CO}_{2}$ evolution, the total amount of evolved $\mathrm{CO}_{2}$ with time was found to correlate with changes in evolved temperature during microbial activity. Meanwhile, during respiration, a process dependent on $\mathrm{O}_{2}$ consumption and evolved $\mathrm{CO}_{2}$, was observed to be highly exothermic. Furthermore, 
heat generation was directly related to the level of metabolic activities of the microorganisms [3]. Motivated by these observations, evaluation of CER data and temperature changes during SSF for both fungi were carried out.

Fig. 9 shows the profiles of temperature changes and CER over time for A. awamori and A. oryzae. The data shown suggest a possible linear dependence between the temperature rise and CER. A straight line with the slope of $2.224{ }^{\circ} \mathrm{C} /$ mole of $\mathrm{CO}_{2}$. Commencement of $\mathrm{CO}_{2}$ evolution occurred during 6 to 24 $\mathrm{h}$ of fermentation for all experiments. Data generated from the increase in temperature revealed a same profile as CER. When the $\mathrm{CO}_{2}$ concentration increases, temperature rises. The relationship between temperature and evolved $\mathrm{CO}_{2}$ is consistent with a feedback between $\mathrm{CO}_{2}$ evolution rate (and might also correspond to oxygen uptake rate, OUR). Temperature rise and rate of $\mathrm{CO}_{2}$ evolution reflect the metabolic activity of the fungus during the SSF process. In every experiment, the temperature rise during SSF was found to correlate with the rate of $\mathrm{CO}_{2}$ evolution. A linear correlation exists between the temperature rise and CER irrespective of the growth rate of the fungus. The correlation between temperature rise and $\mathrm{CO}_{2}$ evolution is very satisfactory; however, it does not permit comparison between processes.

Heat and $\mathrm{CO}_{2}$ are microbially produced, thus indicate the existence of microbial metabolic activity, consumption of $\mathrm{O}_{2}$, evolution of $\mathrm{CO}_{2}$ and utilization of organic carbon [82]. In the case of aerobic microorganisms, the catabolic heat evolution rate is regarded to be proportional to the OUR and CER. According to Cooney et al. [83], if the heat evolution rate transfer ratio is constant, the change of temperature can be calculated by monitoring $\mathrm{O}_{2}$ consumption or $\mathrm{CO}_{2}$ evolution. The rising $\mathrm{CO}_{2}$ levels correlated with rising temperatures because $\mathrm{CO}_{2}$ is believed to trap natural heat from the surface warming of fermented substrate [82]. The study further elaborated that $\mathrm{CO}_{2}$ would enclose the surface and trap heat, causing the fermented bed surface to become insulated and ultimately causing a temperature rise. In addition, the evolution of heat during microbial activity can provide useful data, such as growth rate, lag phase, or maximum growth [69]. In addition, encouragingly, the use of this technique in the biological and biomedical field has been increasing. Examples include detection and characterization of pathogens, drug testing, parasitology and tissue engineering [69].

\section{Effect of air arrangement on spore and enzyme production}

An average value of spore production and levels of enzymatic activities resulted from the moistened air arrangement with different flow rate are shown in Fig. 10 and Fig. 11, respectively. From these observations, A. awamori is an excellent fungus for spores and glucoamylase, xylanase and cellulase production. However, A. awamori is a poor protease producer. A. oryzae is excellent in protease production but poor in glucoamylase, xylanase and cellulase production. This might be because $A$. 
oryzae seemed to favour a solid substrate with high protein content (as a nitrogen source) such as rapeseed meal, and does not favour wheat bran as a main substrate [57]. A. awamori seemed to favour a solid substrate with a high carbohydrate content (as a carbon source) [57].

In all experiments carried for both fungi, moistened air at a flow rate of $1 \mathrm{~L} / \mathrm{min}(\operatorname{Exp} 2)$ favour spores and enzymes production. This strategy was believed to create homogenous conditions in term of an enough supply of $\mathrm{O}_{2}$ concentration while maintaining moisture contents and avoiding bed drying. In Exp 1, a high flow rate of $8 \mathrm{~L} / \mathrm{min}$ tend to create stress in the bioreactor's system, whereby most $\mathrm{O}_{2}$ was "washed" out and concentrations of $\mathrm{O}_{2}$ might be low. A high flow rate also gave some negative effects on the moisture content, especially for A. awamori (Fig. 3). We conclude that with proper strategy to supply air into the bioreactor system for SSF, is advantageous to the fermentation's performance and fungal activity. The strategy suggests that reasonable control of the $\mathrm{O}_{2}$ concentration, bed temperature and moisture content can be achieved by manipulating the flow rate of moistened air. As reported by Perez et al. [4,5], using an inner tube for air supply resulted in more homogeneous enzyme production, with higher activities and solving overheating and gaseous exchanges. However, our results contrast with previous reports by Castro et al., 2015 [84]. In this study SSF in SSB with forced aeration showed high levels of a cocktail of hydrolases (amylases, cellulases, xylanases and proteases) by A. awamori. This was supported by Mendez-Gonzlez et al. [34] which showed that forced aeration during SSF in SSB allows high conidia production and productivity. However, for a better monitoring and good comparison, other solid substrates, different types of microorganisms or fungi and different types of bioreactors, should be investigated.

\section{Conclusion}

This work presented two different moistened aeration strategies in newly-designed multi-layer eight squared tray SSB containing wheat bran to cultivate the fungus A. awamori and A. oryzae by solid state fermentation. Experiments were carried out under sterile conditions, equipped with an online gas analyse and temperature recorder, for continuous $\mathrm{O}_{2}, \mathrm{CO}_{2}$ and metabolic heat measurement. Continuous on-line monitoring of fungal growth could be performed by indirect methods, including monitoring $\mathrm{O}_{2}$ consumption, $\mathrm{CO}_{2}$ and heat evolution during SSF, is very useful to assess the physiological state and respiration rate of culture. Yet, it can directly reveal the activity of the A. awamori and A. oryzae culture in SSF and can be observed as indirect techniques for biomass estimation. Reasonable measure of the final moisture content can be achieved through strategy with moistened air at inlet with a flow rate 8 $\mathrm{L} / \mathrm{min}$ and $1 \mathrm{~L} / \mathrm{min}$. The air flow distribution strategies and the bioreactor with multi-layered trays contributes to an effective air distribution and optimal temperature maintenance. Even though, the final moisture content and temperature profiles for both fungi were little affected by the alternative of airflow 
distribution, one might conclude that the introduction of moistened air produced a better distribution of gas within the bioreactor. $\mathrm{CO}_{2}$ that evolved as a result of metabolic activity during A. awamori and A. oryzae SSF on wheat bran is easy to handle with a simple Gompertz model and fit the integrated $\mathrm{CO}_{2}$ data and predict the quantity of $\mathrm{CO}_{2}$ evolution in all experiments. Measurement of OUR and CER will lead to determination of RQ that gave important information about the fungal growth. In all respective experiments carried out in this work, the RQ values obtained are less than 1. Yet, a strategy with different aeration arrangements improved productivity of fungi, including production of spores and consortium of enzymes (glucoamylase, protease, xylanase and cellulase).

Even though the present study is on a small scale, it is hoped that the multi-layer squared tray SSB systems will provide a greater and general understanding information when looked at in conjunction with other studies in open literature. This work suggests that there will be a remarkable improvement in bioreactor productivity and better fungal growth. Information obtained could have several potential advantages including, contributing to future designs and applications. Some more efforts must be done to improve the performance of the bioreactor; for example further investigations of mass transfer and possibly to scale-up into larger bioreactor by solving problems of overheating and gaseous exchanges.

Acknowledgments To the Malaysian Agricultural Research and Development Institute (MARDI) and Government of Malaysia for providing me an opportunity to further study at University of Manchester, United Kingdom.

Authors' contributions Dr Musaalbakri Abdul Manan was carried the experiments in the laboratory and wrote the article as part of their Ph.D work. Prof. Colin Webb supervised the research activities and helped to review and edit the article before submission. Both authors read and approved the final manuscript.

Conflicts of interest The authors declare that they have no known competing financial interests or personal relationships that could have appeared to influence the work reported in this paper.

Ethical Approval This research articles do not contain any studies with human participants or animals performed by any of the authors. Hence, no format consent is required.

Consent to Publish The authors give their consent to publish this research article.

Consent to Participate The authors give their consent to participate in this research article. 


\section{References}

1. Costa J.A.V., Treichel, H., Kumar, V. and Pandey, A. (2018), Advances in solid-state fermentation, in Current Developments in Biotechnology and Bioengineering: Current Advances in Solid-state Fermentation. (Pandey, A. Larroche, C. and Soccol, C. R., ed.), Elsevier, pp. 1-17. https://doi.org/10.1016/B978-0-444-63990-5.00001-3

2. Wang, R., Gmoser, R., Taherzadeh, M.J., Lennartsson, P.R. (2021), Solid-state fermentation of stale bread by an edible fungus in a semi-continuous plug-flow bioreactor. Biochem. Eng. J. 169, 107959. https://doi.org/10.1016/j.bej.2021.107959

3. Finkler, A.T.J., de Lima Luz Jr, L.F., Krieger, N., Mitchell, D.A. and Jorge, L.M. (2021), A model-based strategy for scaling-up traditional packed-bed bioreactors for solid-state fermentation based on measurement of $\mathrm{O}_{2}$ uptake rates. Biochem. Eng. J. 166, 107854. https://doi.org/10.1016/j.bej.2020.107854

4. Perez, C.L., Casciatori, F.P. and Thomeo, J.C. (2020), Improving enzyme production by solidstate cultivation in packed-bed bioreactors by changing bed porosity and airflow distribution. Bioproc. Biosys. Eng. 44, 537-548. DOI: 10.1007/s00449-020-02466-7

5. Perez. C.L., Casciatori, F.P. and Thomeo, J.C. (2019), Strategies for scaling-up packed-bed bioreactors for solid state fermentation: The case of cellulolytic enzymes production by a thermophilic fungus. Chem. Eng. J. 361, 1142-1151. https://doi.org/10.1016/j.cej.2018.12.169

6. Pitol, L.O., Finkler, A.T.J., Dias, G.S., Machado, A.S., Zanin, G.M., Mitchell, D.A. and Krieger, N. (2017), Optimization studies to develop a low-cost medium for production of the lipases of Rhizopus microspores by solid-state fermentation and scale-up of the process to a pilot packed-bed bioreactor. Proc. Biochem. 62, 37-47. https://doi.org/10.1016/j.procbio.2017.07.019

7. Dilipkumar, M., Rajamohan, N. and Rajasimman, M. (2013), Inulinase production in a packed bed reactor by solid state fermentation. Carboh. Poly. 96, 196-199. https://doi.org/10.1016/j.carbpol.2013.03.078

8. do Nascimento, F.V., de Castro, A.L., Secchi, A.R. and Coelho, M.A.Z. (2021), Insights into media supplementation in solid-state fermentation of soybean hulls by Yarrowia lipolytica: Impact on lipase production in tray and insulated packed-bed bioreactors. Biochem. Eng. J. 166, 107866. https://doi.org/10.1016/j.bej.2020.107866

9. Mahmoodi, M., Najafpour, G.D. and Mohammadi, M. (2019), Bioconversion of agroindustrial wastes to pectinases enzyme via solid state fermentation in trays and rotating drum bioreactors. Biocat. Agri. Biotechnol. 21, 101280. https://doi.org/10.1016/j.bcab.2019.101280

10. Doriya, K. and Kumar, D.S. (2018), Optimization of solid substrate mixture and process parameters for the production of L-asparaginase and scale-up using tray bioreactor. Biocatal. Agri. Biotechnol. 13, 244-250. https://doi.org/10.1016/j.bcab.2018.01.004

11. Khanahmadi, M., Arezi, I., Amiri, M. and Miranzadeh, M. (2018). Bioprocessing of agroindustrial residues for optimization of xylanase production by solid-state fermentation in flask and tray bioreactor. Biocatal. Agri. Biotechnol. 13, 272-282. https://doi.org/10.1016/j.bcab.2018.01.005. 
12. Vaseghi, Z., Najafpour, G.D., Mohseni, S. and Mahjoub, S. (2012), Production of active lipase by Rhizopus oryzae from sugarcane bagasse: Solid state fermentation in a tray bioreactor. Int. J. Food. Sci. Technol. 48(2), 283-289. https://doi.org/10.1111/j.1365-2621.2012.03185.x

13. Shahryani, Z., Fazaelipoor, M.H., Shaabani, M.S. and Ghasemi, Y. (2019), Production of fungal phytase in an innovative trickle bed bioreactor. Waste Biomass Valor. 11, 3273-3280. https://doi.org/10.1007/s12649-019-00642-9

14. Avila, S.N.S., Gutarra, M.L.E., Fernandez-Lafuente, R., Cavalcanti, E.D.C..and Freire, D.M.G. (2019), Multipurposes fixed-bed bioreactor to simplify lipase production by solid-sate fermentation and application in biocatalysis. Biochem. Eng. J. 144, 1-7, https://doi.org/10.1016/j.bej.2018.12.024

15. Dhillon, G.S., Brar, S.K., Kaur, S. and Verma, M. (2013), Bioproduction and extraction optimization of citric acid from Aspergillus niger by rotating drum type solid-state bioreactor. Ind. Crop Prod. 41, 78-84. DOI: 10.1016/j.indcrop.2012.04.001

16. Rodriguez-Fernandez, D.E., Rodriguez-Leon, J.A., de Carvalho, J.C., Sturm, W. and Soccol, C.R. (2011), The behaviour of kinetic parameters in production of pectinase and xylanase by solid-state fermentation. Biores. Technol. 102, 10657-10662, https://doi.org/10.1016/j.biortech.2011.08.106

17. Ruiz, H.A., Rodríguez-Jassoa, R.M., Rodríguez, R., Contreras-Esquivel, J.C. and Aguilar, C.N. (2012), Pectinase production from lemon peel pomace as support and carbon source in solidstate fermentation column-tray bioreactor. Biochem. Eng. J. 65, 90-95, https://doi.org/10.1016/j.bej.2012.03.007

18. Brijwani, K., Vadlani, P.V., Hohn, K.L. and Maier, D.E. (2011), Experimental and theoretical analysis of a novel deep-bed solid-sate bioreactor for cellulolytic enzymes production. Biochem. Eng. J. 58-59, 110-123. https://doi.org/10.1016/j.bej.2011.09.004

19. Mitchell, D.A., Berovic, M.and Krieger, N. (2006), Introduction to solid-state bioreactors, in Solid State Fermentation Bioreactors - Fundamentals of Design and operation (Mitchell, D.A., Krieger, N. and Berovic, M., ed). Springer-Verlag Berlin Heidelberg, Germany, pp. 33-44. DOI: $10.1007 / 3-540-31286-2$

20. Jang, H.D. and Yang, S.S. (2008), Polyunsaturated fatty acids production with a solid-state column reactor. Biores. Technol. 99(14), 6181-6189. https://doi.org/10.1016/j.biortech.2007.12.024

21. Foong, C.W., Krishnaiah, K., Janaun, J., Subbarao, D. and Prabhakar, A. (2009), Heat and mass transfer studies of palm kernel cake (PKC) in fluidized bed fermenter. Ind. Crops Prod. 30, 227-234. https://doi.org/10.1016/j.indcrop.2009.03.012

22. da Cunha, D.C., Souza, J.A., Rocha, L.A.O. and Costa, J.A.V. (2009), Hexahedral modular bioreactor for solid state bioprocesses. World J. Microbiol. Biotechnol. 25, 2173-2178. https://doi.org/10.1007/s11274-009-0122-3

23. Takashi, A., Yuan, J.G., Shinji, M., Shahedur, R.M., Kasumasa, O. and Makoto, S. (2009), Solid state fermentation of lipopeptide antibiotic iturin A by using a novel solid state fermentation reactor system. J. Environ. Sci. 21(1), S162-S165. https://doi.org/10.1016/S10010742(09)60064-4

24. Alam, M.Z., Mamun, A.A., Qudsieh, I.Y., Muyibi, S.A., Salleh, H.M. and Omar, N.M. (2009), Solid state bioconversion of oil palm empty fruit bunches for cellulase enzyme production using 
a rotary drum bioreactor. Biochem. Eng. J. 46(1), 61-64. https://doi.org/10.1016/j.bej.2009.03.010

25. Varzakas, T.H., Roussos, S. and Arvanitoyannis, I.S. (2008), Glucoamylases production of Aspergillus niger in solid state fermentation using a continuous counter-current reactor. Int. J. Food Sci. Technol. 43(7), 1159-1168. https://doi.org/10.1111/j.1365-2621.2007.01582.x

26. Nagel, F.J.J.I., Tramper, J., Bakker, M.S.N. and Rinzema, A. (2001), Temperature control in a continuously mixed bioreactor for solid-state fermentation. Biotechnol. Bioeng. 72(2), 219230. https://doi.org/10.1002/1097-0290(20000120)72:2<219::AID-BIT10>3.0.CO;2-T

27. Mitchell, D.A. and von Meien, O.F. (2000), Mathematical modelling as a tool to investigate the design and operation of the zymotis packed bed-bioreactor for solid state fermentation. Biotechnol. Bioeng. 68(2), 127-135. https://doi.org/10.1002/(SICI)10970290(20000420)68:2<127::AID-BIT1>3.0.CO;2-K

28. Silva, E.M. and Yang, S.T. (1998), Production of amylases from rice by solid-state fermentation in a gas-solid spouted-bed bioreactor. Biotechnol. Prog. 14, 580-587. https://doi.org/10.1021/bp9800440

29. Berovic, M. and Ostroversnik, H. (1997), Production of Aspergillus niger pectolytic enzymes by solid state bioprocessing of apple pomace. J. Biotechnol. 53(1), 47-53. https://doi.org/10.1016/S0168-1656(96)01661-6

30. Bandelier, S., Renaud, R. and Durand, A, (1997), Production of gibberellic acid by fed-batch solid state fermentation in an aseptic pilot-scale. Proc. Biochem. 32(2), 141-145. https://doi.org/10.1016/S0032-9592(96)00063-5

31. Gutierrez-Rojas, M., Aboul Hosn, S.A., Auria, R., Revah, S. and Favela-Torres, E. (1996), Heat transfer in citric acid production by solid state fermentation. Proc. Biochem. 31(4), 363-369. https://doi.org/10.1016/0032-9592(95)00071-2

32. Torres-Leon, C., Chavez-Gonzalez, L.M., Hernadez-Almanza, A., Martinez-Medina, G.A., Ramirez-Guzman, N., Londono-Hernadez, L. and Aguilar, C.N. (2021), Recent advances on the microbiological and enzymatic processing for conversion of food wastes to valuable bioproducts. Curr. Op. Food Sci. 38, 40-45. https://doi.org/10.1016/j.cofs.2020.11.002

33. Arora, S., Rani, R. and Ghosh, S. (2018), Bioreactors in solid state fermentation technology: Design, applications and engineering aspects. J. Biotechnol. 269, 16-34. https://doi.org/10.1016/j.jbiotec.2018.01.010

34. Mendez-Gonzalez, F., Loera, O., Saucedo-Castaned, G. and Favela-Torres, E. (2020), Forced aeration promotes high production and productivity of infective conidia from Metarhizium robertsii in solid-state fermentation. Biochem. Eng. J. 156, 107492. https://doi.org/10.1016/j.bej.2020.107492

35. El Zein, A., Seif, H. and Gooda, E. (2015), Moisture content and thermal balance during composting of fish, banana mulch and municipal solid wastes. European Scientific J. 11(5), 169-187. https://eujournal.org/index.php/esj/article/view/5183.

36. Garcia-Ochoa, F. and Gomez, E. (2009), Bioreactor scale-up and oxygen transfer rate in microbial processes: An overview. Biotechnol. Adv. 27(2), 153-176. https://doi.org/10.1016/j.biotechadv.2008.10.006 
37. Liang, C., Das, K.C. and McClendon, R.W. (2003), The influence of temperature and moisture contents regimens on the aerobic microbial activity of a biosolids composting blend. Biores. Technol. 86(2),131-137. https://doi.org/10.1016/S0960-8524(02)00153-0

38. Torres-Mancera, M., Figueroa-Mantero, A., Favela-Torres, E., Rosales-Zamora, E.G., Nampoothiri, K.M. and Saucedo-Castaneda, G. (2018), Online monitoring of solid-state fermentation using respirometry, in Current Developments in Biotechnology and Bioengineering, (Pandey, A., Larroche, C. and Soccol, C.R., ed.), Elsevier, pp. 97-108. https://doi.org/10.1016/B978-0-444-63990-5.00006-2

39. Zhong, J.J. (2011), Bioreactor engineering, 3rd ed., in Comprehensive Biotechnology, (MooYoung, M., ed.), Elsevier, pp. 165-177. https://doi.org/10.1016/B978-0-08-088504-9.00097-0

40. Nadal-Rey, G., McClure, D.D., Kavanagh, J.M., Cornelissen, S., Fletcher, D.F. and Gernaey, K.V. (2020), Understanding gradients in industrial bioreactors. Biotechnol. Adv. 46, 107660. https://doi.org/10.1016/j.biotechadv.2020.107660

41. Krishna, C. (2005), Solid-state fermentation System - An overview. Crit. Rev. Biotechnol. 25, 1-30. https://doi.org/10.1080/07388550590925383

42. Sindhu, R., Pandey, A. and Binod, P. (2017), Design and types of bioprocesses, in Current Developments in Biotechnology and Bioengineering - Bioprocess, Bioreactors and Controls, (Larroche, C., Sanroman, M.A., Du, G. and Pandey, A., ed.), Elsevier, pp. 29-43. https://doi.org/10.1016/B978-0-444-63663-8.00002-1

43. Pandey A, Soccol CR, Laroche C (2008) General and fundamentals aspects of SSF Introduction, in Current Development in Solid-state Fermentation, (Pandey, A., Soccol, C.R. and Laroche, C., ed.), Springer Science + Business Media, LLC, pp. 3-12. https://doi.org/10.1007/978-0-387-75213-6

44. Ashok, A., Doriya, K., Rao, D.R.M. and Kumar, D.S. (2017), Design solid state bioreactor for industrial applications: An overview to conventional bioreactors. Biocatal. Agri. Biotechnol. 9, 11-18. https://doi.org/10.1016/j.bcab.2016.10.014

45. Deive, F.J. and Sanroman, M.A. (2017), Bioreactor development for the cultivation of extremophilic microorganisms, in Current developments in Biotechnology and Bioengineering - Bioprocess, Bioreactors and Controls, (Larroche, C., Sanroman M., Du, G. and Pandey, A., ed.), Elsevier, pp. 403-432. https://doi.org/10.1016/B978-0-444-63663-8.00014-8

46. Sukatsch, D.A. and Dziengel, A. (1987), Biotechnology: A handbook of practical formulae. Longman Scientific and Technical, Essex, John Wiley and Sons, Inc. New York. Pp. 104-105. ISBN 0-582-98899-3.

47. Winsor, C.P. (1932), The Gompertz curve as a growth curve. Proc. Natl. Acad. Sci. 18(1), 18. DOI: $10.1073 /$ pnas.18.1.1

48. Skiadas, C.H. and Skiadas, C. (2008), Comparing the Gompertz models with a first passage time density model, in Advances in data analysis, (Skiadas, C.H., ed.), Springer, Birkhauser Boston. pp. 203-209. DOI: 10.1007/978-0-8176-4799-5_18

49. Saucedo, G.C., Gonzalez, P.B., Revah, S.M., Viniegra, G..G and Raimbault, M. (1990), Effect of Lactobacilli inoculation on cassava (Manihot esculenta) silage: Fermentation pattern and kinetic analysis. J. Sc. Food. Agri. 50(40, 467-477. https://doi.org/10.1002/jsfa.2740500405 
50. Meraz, M., Shirai, K., Larralde, P. and Revah, S. (1992), Studies on the bacterial acidification process of cassava (Manihot esculenta). J. Sc. Food. Agri. 60(4), 457-463. https://doi.org/10.1002/jsfa.2740600409

51. Christen, P., Meza, J.C. and Revah, S. (1997), Fruity aroma production in solid state fermentation by Ceratocystis fimbriata: Influence of the substrate type and the presence of precursors. Mycological Res. 101(8), 911-919. https://doi.org/10.1017/S0953756297003535

52. Ariff, A.B. and Webb, C. (1996), Influence of different fermenter configurations and modes of operation on glucoamylase production by Aspergillus awamori. Asia Pacific J. Mol. Bio. Biotechnol. 4, 183-195.

53. Wang, R.H. (1999), Continuous production of generic fermentation feedstock from whole wheat flour. Phd Thesis. The University of Manchester Institute of Science and Technology, Manchester, United Kingdom.

54. Bailey, M.J., Bieley, P. and Poutanen, K. (1992), Interlaboratory testing of methods for assay of xylanase activity. J. Biotechnol. 23, 257-270. https://doi.org/10.1016/0168-1656(92)90074$\mathrm{J}$

55. Adney, B. and Baker, J. (2008), Measurement of cellulase activities: Laboratory analytical procedure (LAP), Technical Report NREL/TP-510-42628. National Renewable Energy Laboratory. U.S.

56. Ghose, T.K. (1987), Measurement of cellulase activities. Pure App. Chem. 59(2), 257268. https://doi.org/10.1351/pac198759020257

57. Abdul Manan, M. and Webb, C. (2016), Multi-enzymes production studies in single tray solid state fermentation with opened and closed system. J. Life Sci. 10, 342-356. DOI: 10.17265/1934-7391/2016.07.005

58. Abdul Manan, M. and Webb, C. (2016), Water retention value: A study model-based by Aspergillus awamori and Aspergillus oryzae embrace three models of solid substrates. J. Life Sci. 8, 420-429. DOI:10.17265/1934-7391/2016.08.008

59. Ma, H., Li, Z., Yin, F., Kao, W., Yin, Y. and Bai, X. (2014), Study on aerobic treatment of hazardous steel-mill waste rolling oil (SmWRO) for multi-benefit disposal route. Biores. Technol. 151, 106-112. https://doi.org/10.1016/j.biortech.2013.10.051

60. Naveena, B., Sakthiselvan, P., Elaiyaraju, P. and Partha, N. (2012), Ultrasound induced production of thrombinase by marine actinomycetes: Kinetic and optimization studies. Biochem. Eng. J. 61, 34-42. https://doi.org/10.1016/j.bej.2011.12.007

61. Gil, M.M., Brandao, T.R.S. and Silva, C.L.M. (2006), A modified Gompertz model to predict microbial inactivation under time-varying temperature conditions. J. Food Eng. 76, 89-94. https://doi.org/10.1016/j.jfoodeng.2005.05.017

62. Kafle, G.K. and Kim, S.H. (2013), Anaerobic treatment of apple waste with swine manure for biogass production: Batch and continuous operation. App. Energy. 103, 61-72. https://doi.org/10.1016/j.apenergy.2012.10.018

63. Li, M., Niu, H., Zhao, G., Tian, L., Huang, X., Zhang, J., Tian, W. and Zhang, Q. (2013), Analysis of mathematical models of Pseudomonas spp. growth in pallet-package pork stored at different temperatures. Meat Sc. 93(4), 855-864. https://doi.org/10.1016/j.meatsci.2012.11.048 
64. Augustine, A., Joseph, I., Raj, P.R. and David, N.S. (2015), Growth kinetic profiles of Aspergillus niger S14 a mangrove isolate and Aspergillus oryzae NCIM 1212 in solid state fermentation. Indian J. Fisheries. 62(3), 100-106. ISSN 0970-6011

65. Mitchell, D.A., von Meien, O.F., Krieger, N. and Dalsenter, F.D.H. (2004), A review of recent developments in modelling of microbial growth kinetics and intraparticle phenomena in solidstate fermentation. Biochem. Eng. J. 17(1), 15-26. https://doi.org/10.1016/S1369$703 \mathrm{X}(03) 00120-7$

66. Soares, M., Christen, P., Pandey, A. and Soccol, C.R. (2000), Fruity flavor production by Ceratocystis fimbriata grown on coffee husk in solid-state fermentation. Proc. Biochem. 35(8), 857-861. https://doi.org/10.1016/S0032-9592(99)00144-2

67. Erkmen, O. (2008), Modelling the effects of sucuk production technique on Listeria monocytogenes, aerobic bacteria and lactic acid bacteria during ripening and storage. Food Bioprod. Proc. 86(3), 220-226. https://doi.org/10.1016/j.fbp.2007.10.002

68. Zhu, Z., Sun, L., Huang, X., Ran, W. and Shen, Q. (2014), Comparison of the kinetics of lipopeptide production by Bacillus amyloliquefaciens XZ-173 in solid-state fermentation under isothermal and non-isothermal conditions. World J. Microbiol. Biotechnol. 30, 1615-1623. DOI: $10.1007 / \mathrm{s} 11274-013-1587-7$

69. Braissant, O., Bonkat, G., Wirz, D. and Bachmann, A. (2013), Microbial growth and isothermal microcalorimetry: Growth and their application to microcalorimetric data. Thermochimica Acta. 555, 64-71. https://doi.org/10.1016/j.tca.2012.12.005

70. Mitchell, D.A., Berovic, M., von Meien, O.F. and Luz Jr, L.F.L. (2006), Basics of heat and mass transfer in solid-state fermentation bioreactors, in Solid-state Fermentation Bioreactors Fundamentals of Design and Operation, (Mitchell, D.A., Krieger, N. and Berovic, M., ed.), Springer-Verlag Berlin Heidelberg, Germany, pp. 45-56. DOI: 10.1007/3-540-31286-2

71. Ikasari, L. and Mitchell, D.A. (1998), Oxygen uptake rate kinetics during solid state fermentation with Rhizopus oligosporus. Biotechnol. Tech. 12(2), 171-175. DOI: 10.1023/a:1008805004361

72. Finkler, A.T.J., Weber, M.Z., Fuchs, G.A., Scholz, L.A., de Lima Luz Jr, L.F., Krieger, N., Mitchell, D.A. and Jorge, L.M. (2021), Estimation of heat and mass transfer coefficients in a pilot packed-bed solid-state fermentation bioreactor. Chem. Eng. J. 408, 127246. https://doi.org/10.1016/j.cej.2020.127246

73. Gomez-Ramos, G.A., Castillo-Araiza, C.O., Huerta-Ochoa, S., Couder-Garcia, M. and PradoBarragan, A. (2019), Assessment of hydrodynamics in a novel bench-scale wall-cooled packed bioreactor under abiotic conditions. Chem. Eng. J. 375, 121945. https://doi.org/10.1016/j.cej.2019.121945

74. Pandey, A., Soccol, C.R., Rodriguez-Leon, J.A. and Nigam, P.S. (2001), Solid-state fermentation in Biotechnology: Fundamentals and Application, 1st ed., ASISTECH PUBLISHERS, INC. New Delhi.

75. Rodríguez-León, J.A., de Carvalho, J.C., Pandey, A., Soccol, C.R. and Rodríguez-Fernández, D.E. (2018), Kinetics of the solid-state fermentation process in Current Developments in Biotechnology and Bioengineering - Current Advances in Solid-state Fermentation, (Pandey A, Larroche, C. and Soccol, C.R., ed.), Elsevier, pp. 57-82. https://doi.org/10.1016/B978-0444-63990-5.00004-9 
76. Okazaki, N., Sugama, S. and Tanaka, T. (1980), Mathematical model for surface culture of koji mold: Growth of koji mold on the surface of steamed rice grains (IX). J. Fermen. Technol. 58(5), 471-476.

77. Rajagopalan, S. and Modak, J. (1995), Modelling of heat and mass transfer for solid state fermentation process in tray bioreactor. Bioproc. Biosys. Eng. 13(3), 161-169. DOI: $10.1007 / \mathrm{BF} 00369700$

78. Govind, R., Gao, C., Lai, L. and Tabak, H.H. (1997), Continuous, automated and simultaneous measurement of oxygen uptake and carbon dioxide evolution in biological systems. Water Env. Res. 69(1), 73-80. https://www.jstor.org/stable/25044844

79. Becerra, M. and Gonzalez-Siso, M.I. (1996), Yeast $\beta$-galactosidase in solid state fermentations. Enz. Microb. Technol. 19(1), 39-44. https://doi.org/10.1016/0141-0229(95)00180-8

80. Barrios-Gonzalez, J., Gonzalez, H. and Mejia, A. (1993), Effect of particle size, packing density and agitation on Penicillin production in solid state fermentation. Biotechnol. Adv. 7, 539-547. https://doi.org/10.1016/0734-9750(93)90022-F

81. Mann, M., Huser, A., Schick, B., Dinger, R., Miebach, K. and Buchs, J. (2021), Online monitoring of gas transfer rates during $\mathrm{CO}$ and $\mathrm{CO} / \mathrm{H}^{2}$ gas fermentation in quasi-continuously ventilated shake flasks. Biotechnol. Bioeng. 118, 2092-2104. https://doi.org/10.1002/bit.27722

82. Hendry, M.J., Lawrence, J.R., Zanyk, B.N. and Kirkland, R. (1993), Microbial production of $\mathrm{CO}_{2}$ in unsaturated geologic media in a Mesoscale model. Water Resour. Res. 29(4), 973-984, https://doi.org/10.1029/92WR02847.

83. Cooney, C.L., Wang, D.I.C. and Mateles, R.I. (1968), Measurement of heat evolution and correlation with oxygen consumption during microbial growth. Biotechnol. Bioeng. 1(3), 269281. https://doi.org/10.1002/bit.260110302.

84. Castro, A.M., Castilho, L.R. and Freire, D.M.G. (2015), Performance of a fixed-bed solid-state fermentation bioreactor with forced aeration for the production of hydrolases by Aspergillus awamori. Biochem. Eng. J. 93, 303-308. https://doi.org/10.1016/j.bej.2014.10.016 

Figures

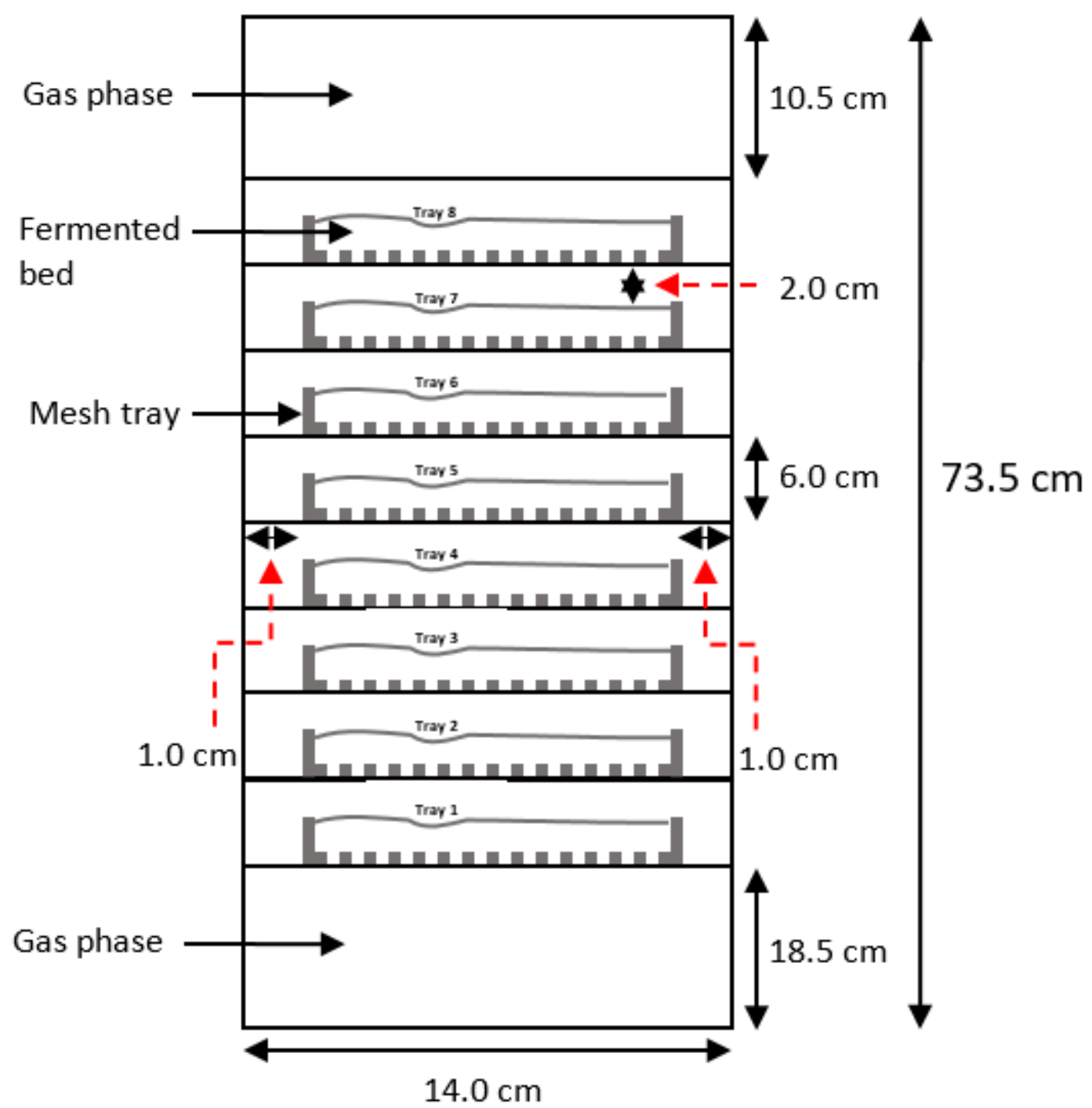

Figure 1

A schematic of a multi-layer tray SSB viewed from the side, with emphasis on the location of the tray 


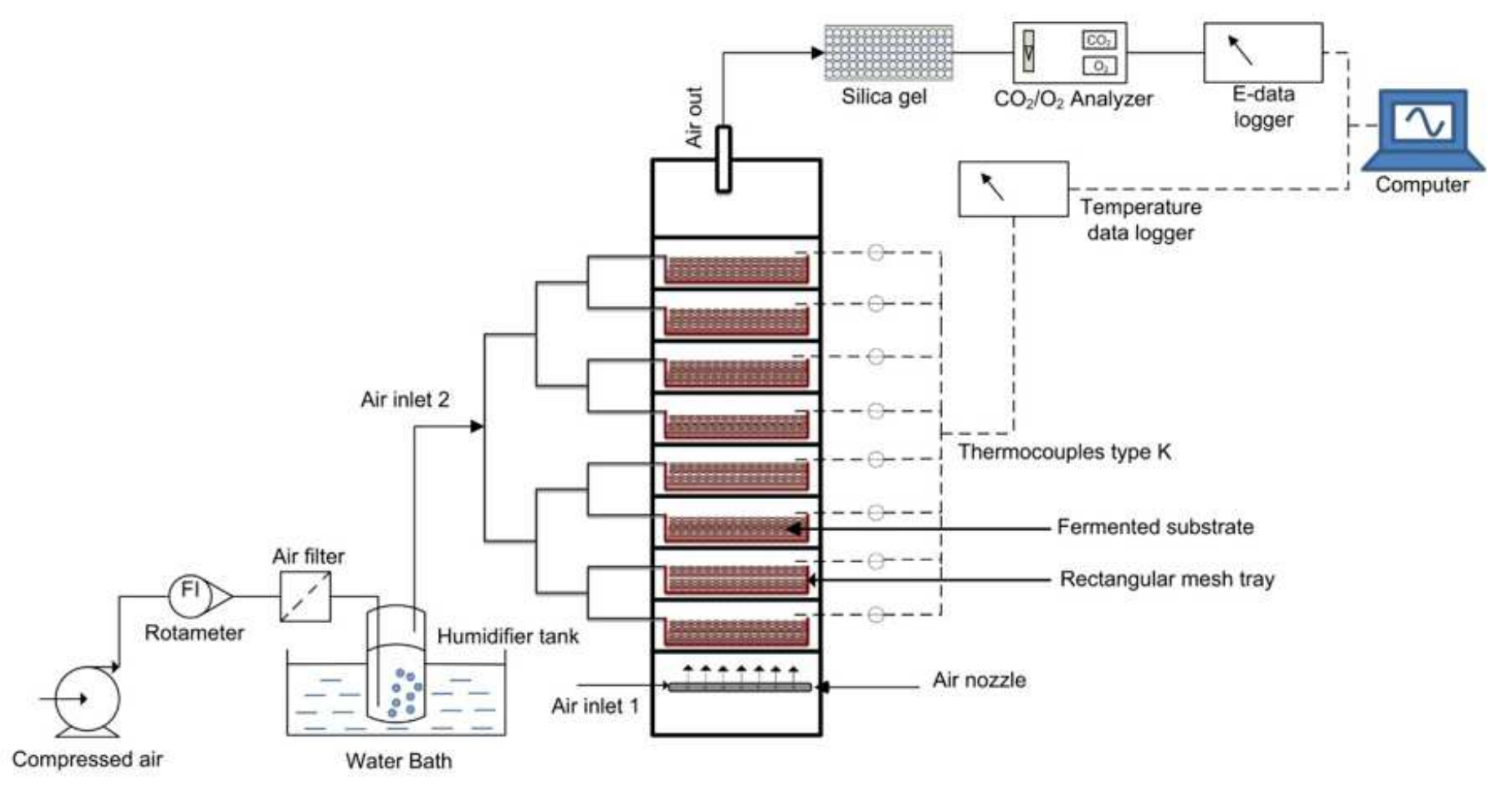

\section{Figure 2}

A schematic diagram of the experimental set-up of a multi-layer squared tray SBB

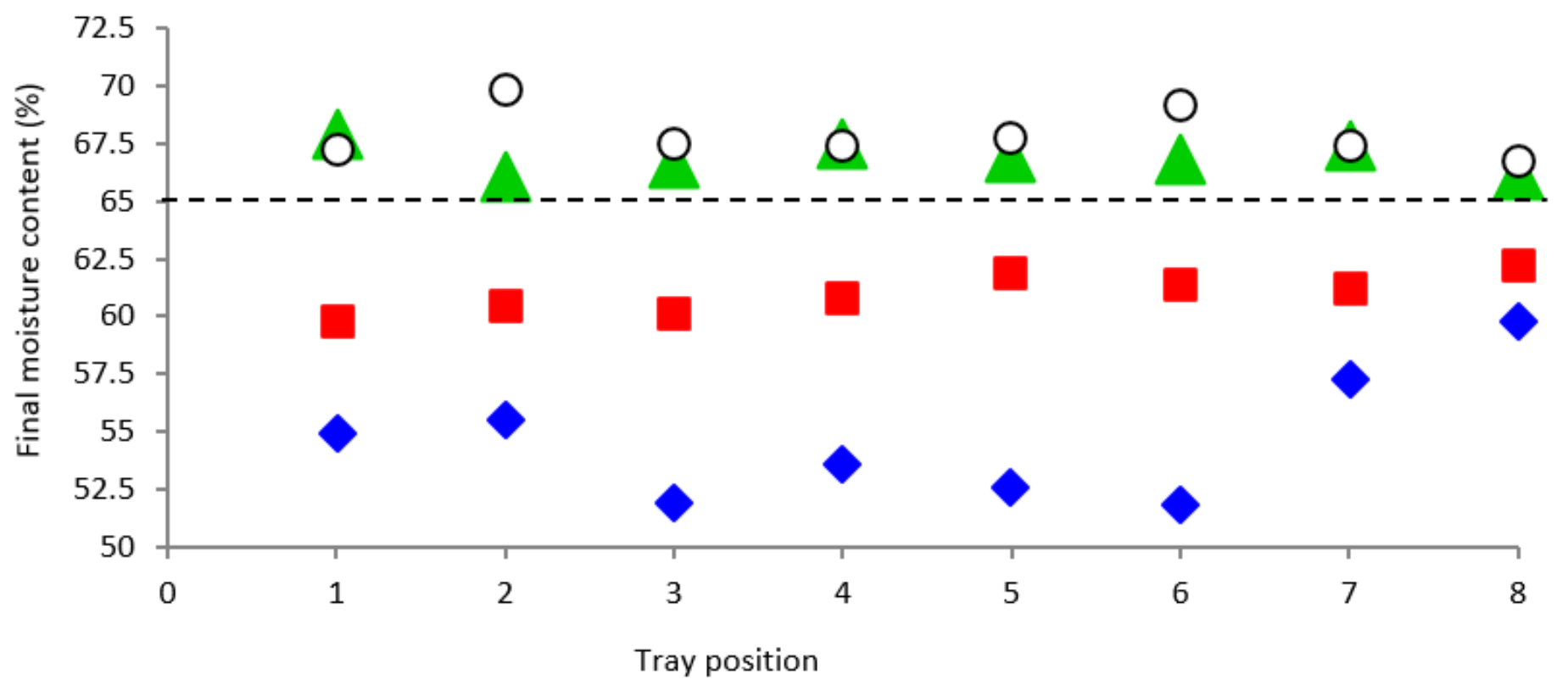

Figure 3

"See the Supplemental Files section for the complete figure caption" 

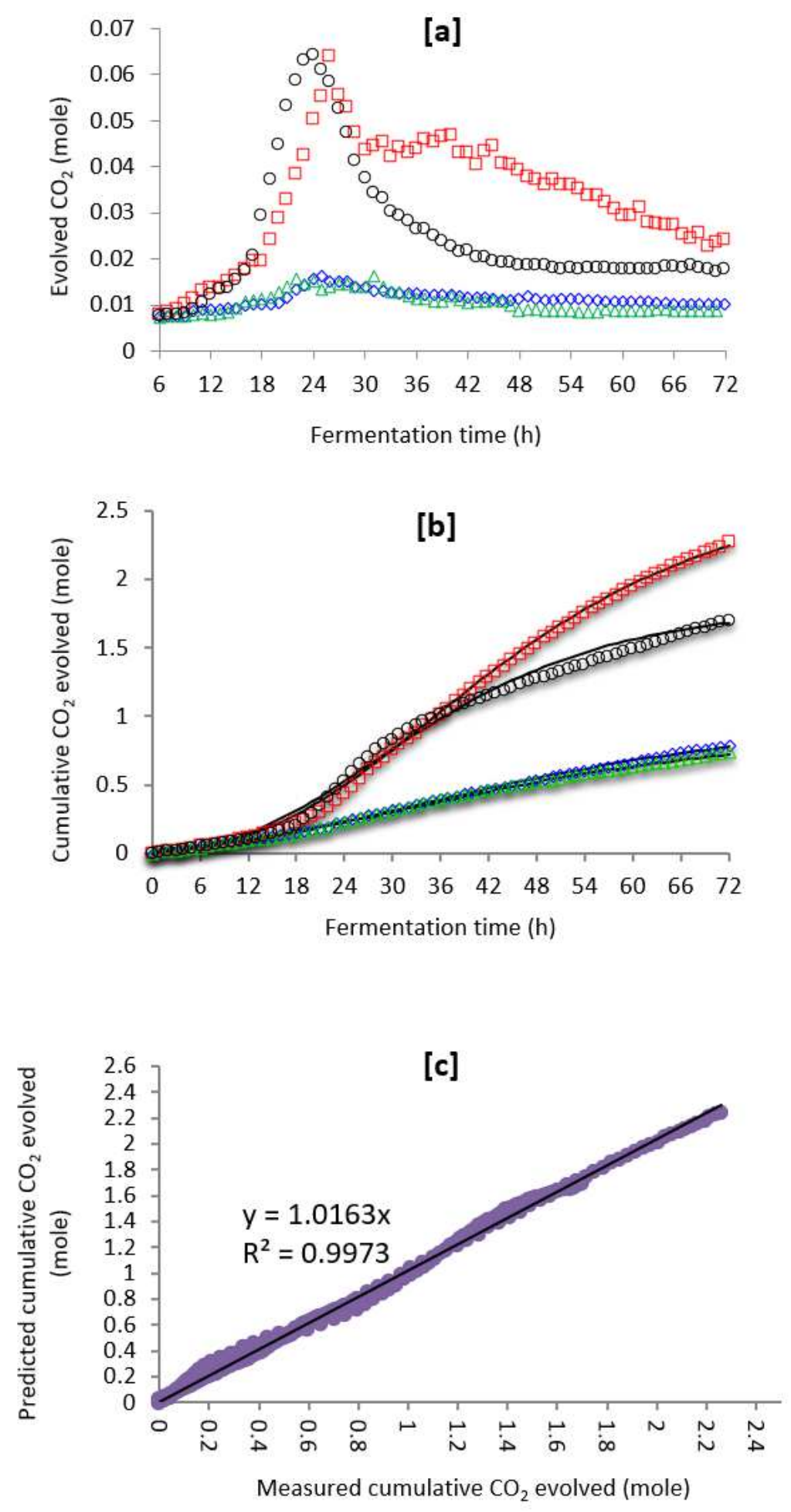

\section{Figure 4}

"See the Supplemental Files section for the complete figure caption" 
$\operatorname{Exp} 1[\mathrm{AA}]$
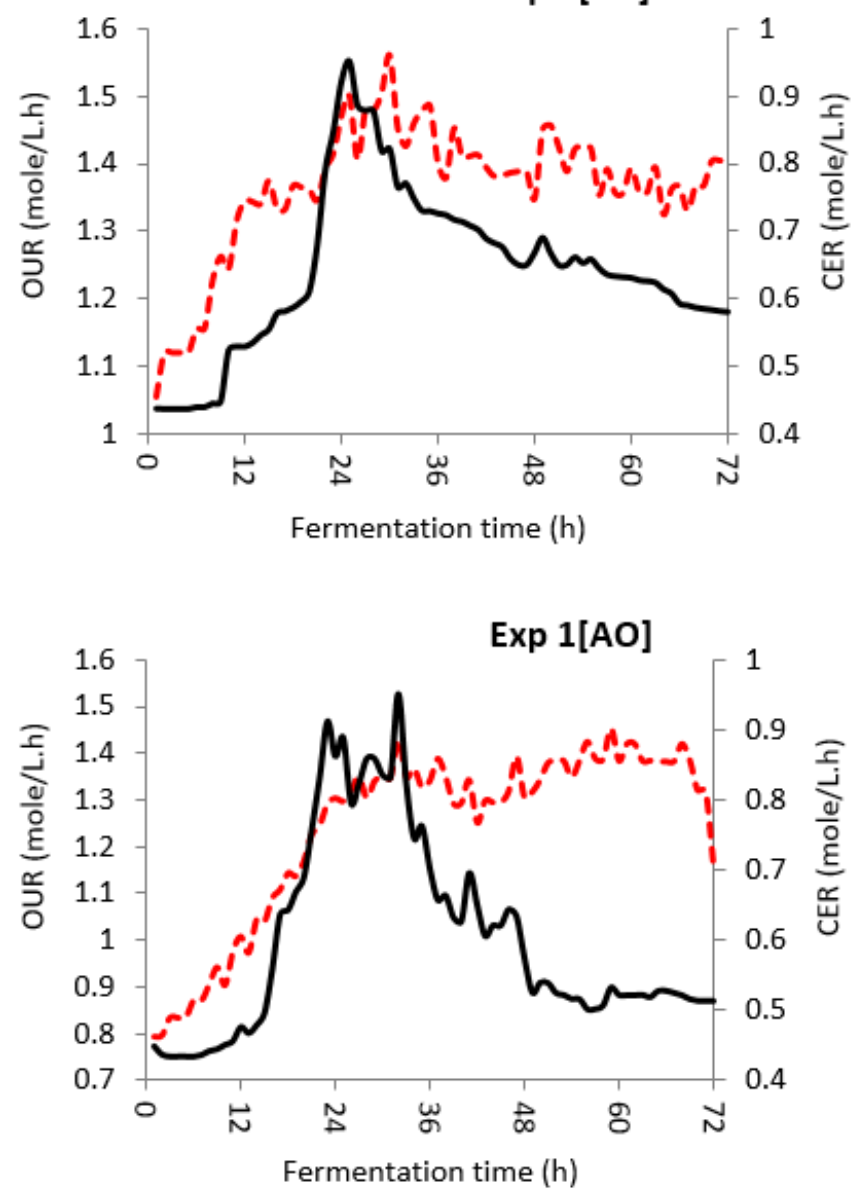
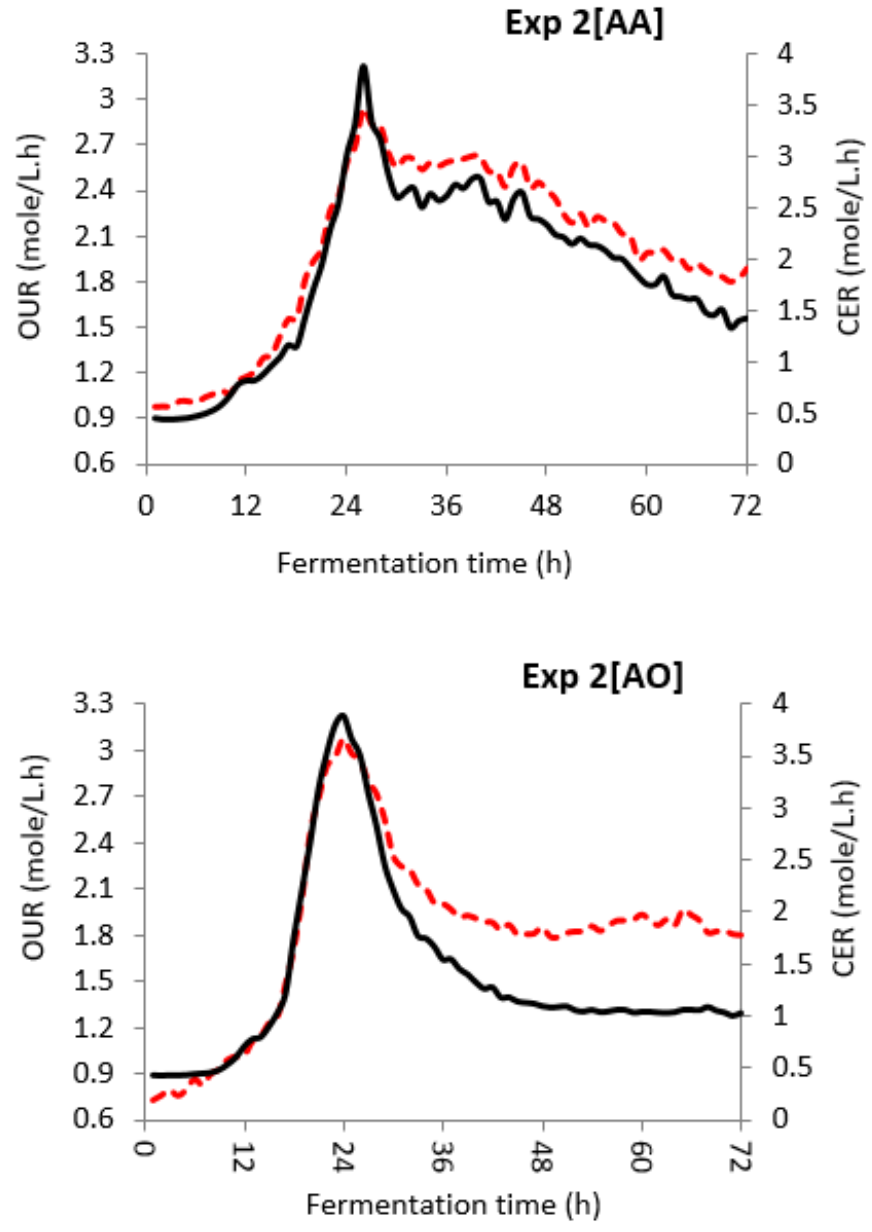

Figure 5

"See the Supplemental Files section for the complete figure caption" 


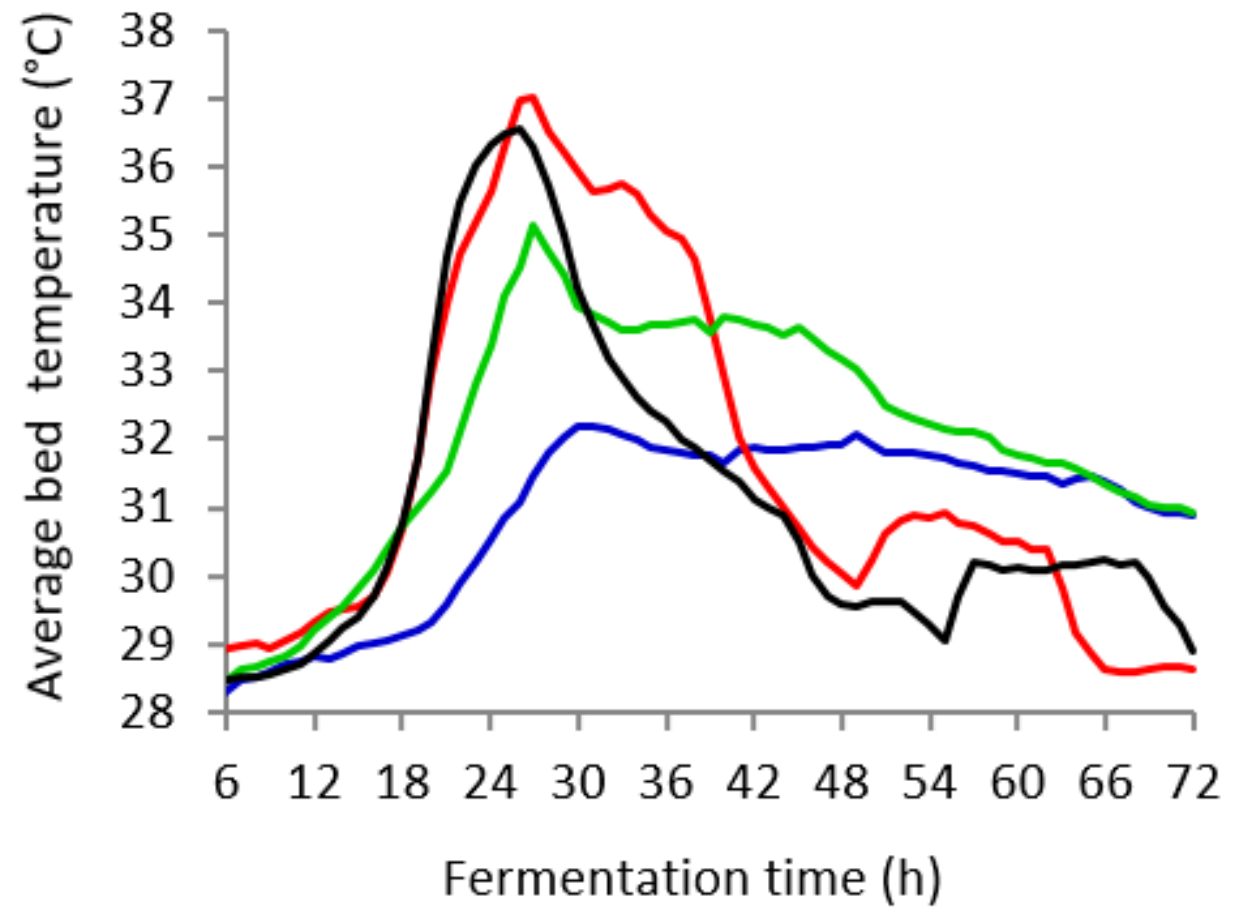

Figure 6

"See the Supplemental Files section for the complete figure caption" 
[a]
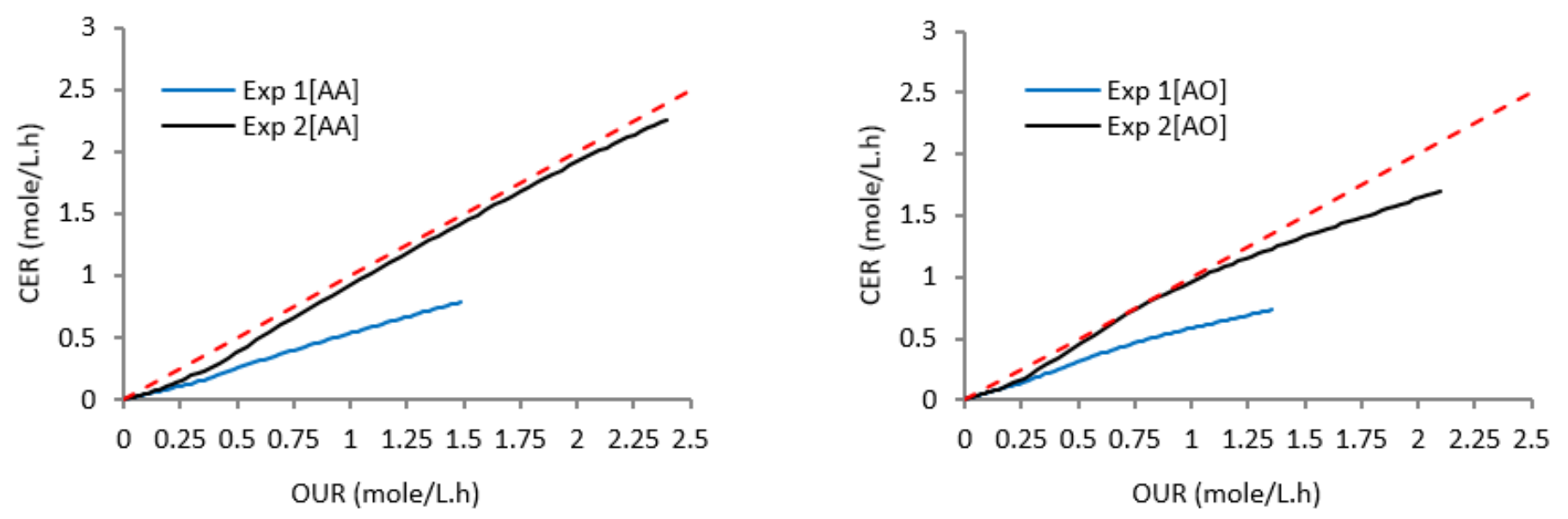

[b]

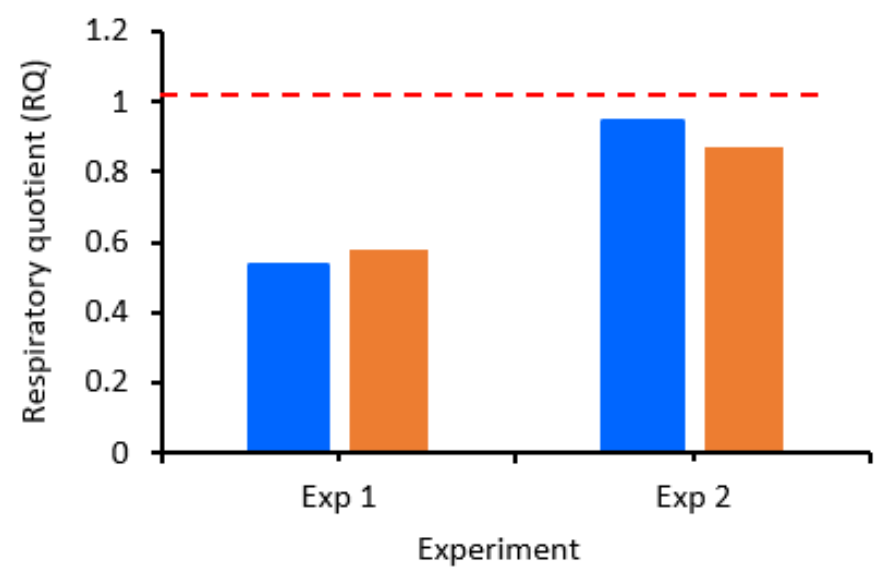

Figure 7

"See the Supplemental Files section for the complete figure caption" 


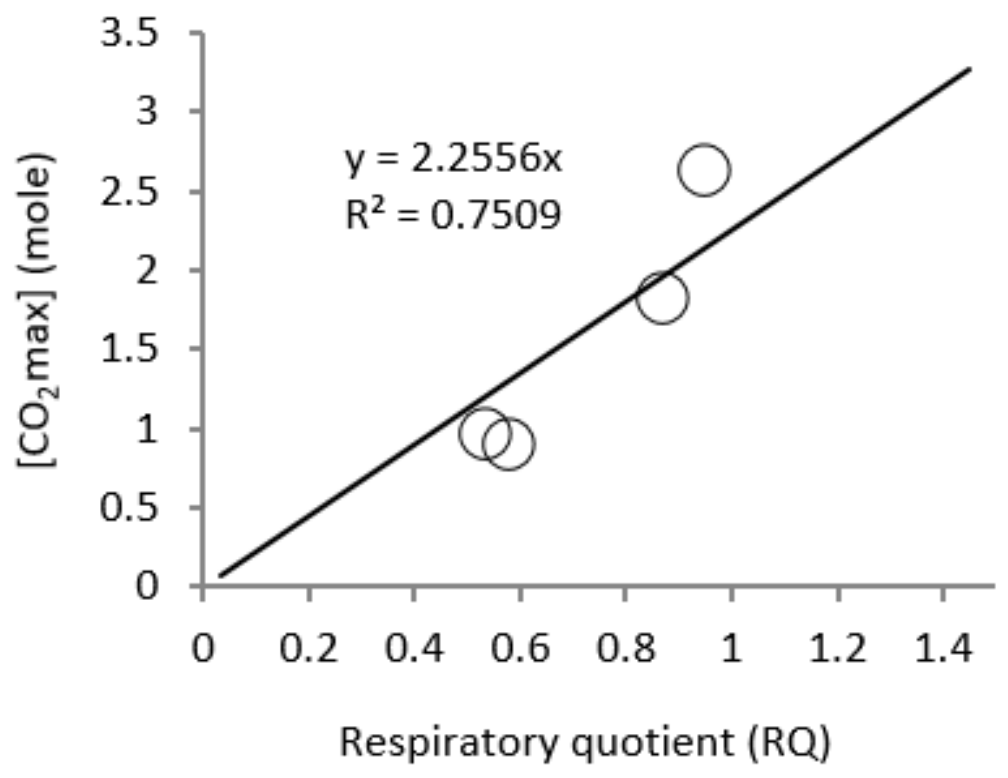

Figure 8

"See the Supplemental Files section for the complete figure caption"

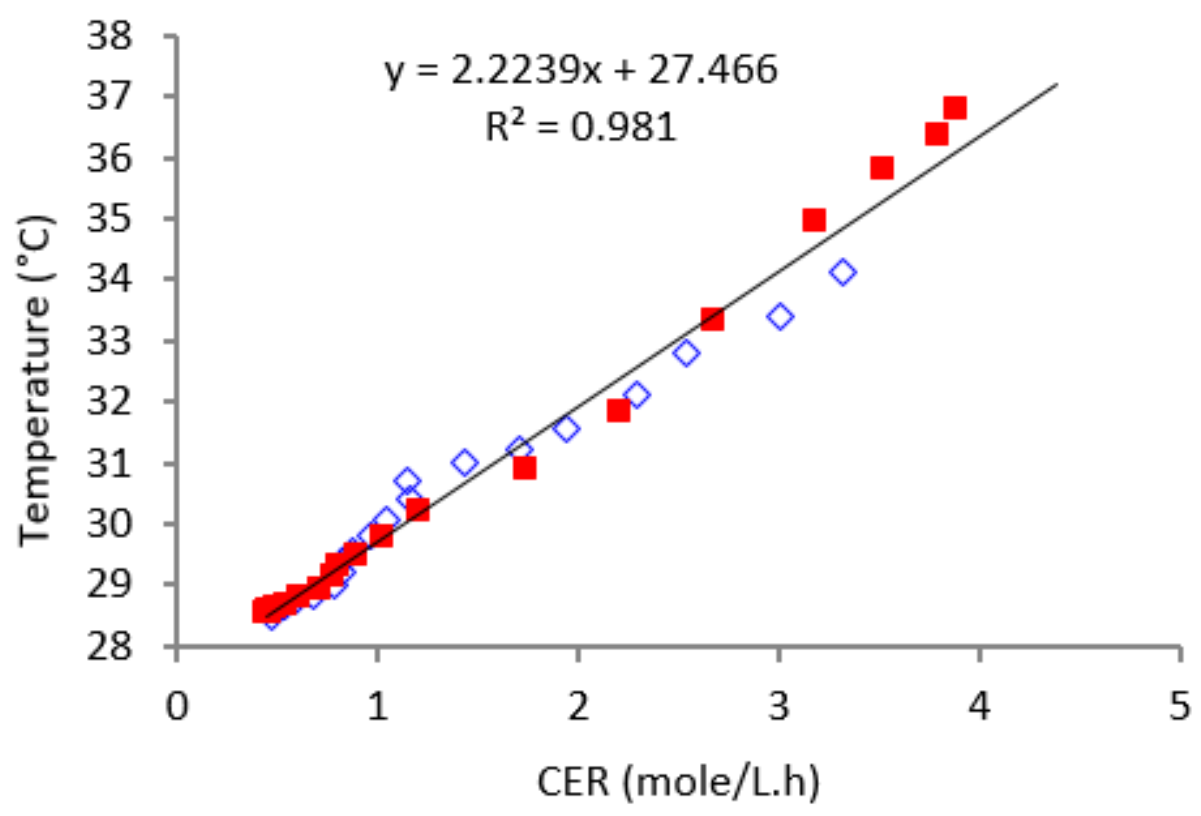

Figure 9

"See the Supplemental Files section for the complete figure caption" 


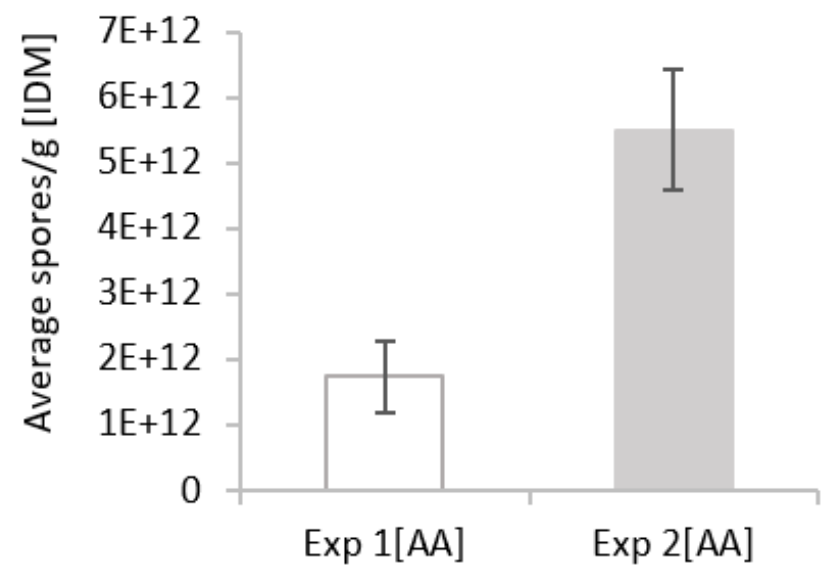

Experiment

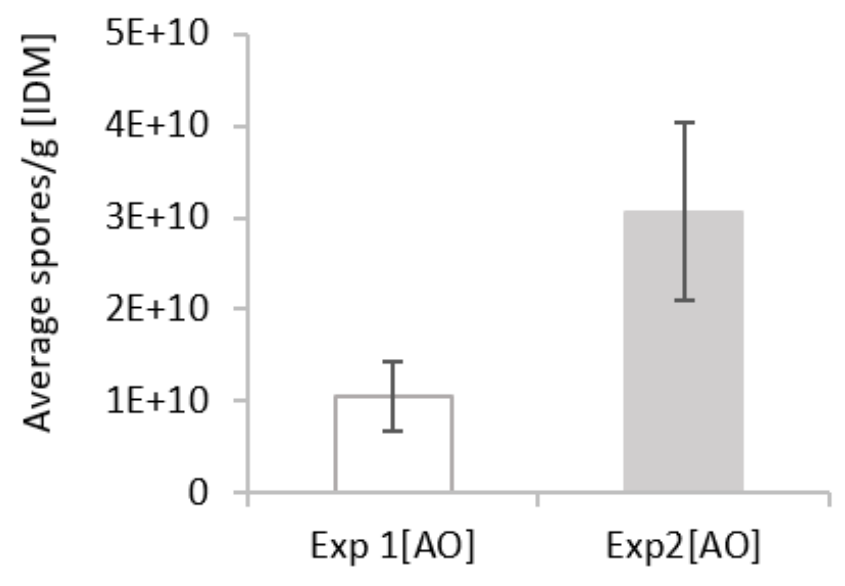

Experiment

Figure 10

Fermentation summary of average spores' production from multi-layer tray SSB with two air arrangements. [AA] - A. awamori and [AO] - A. oryzae. The results are shown as an average from eight trays and mean \pm standard deviation 

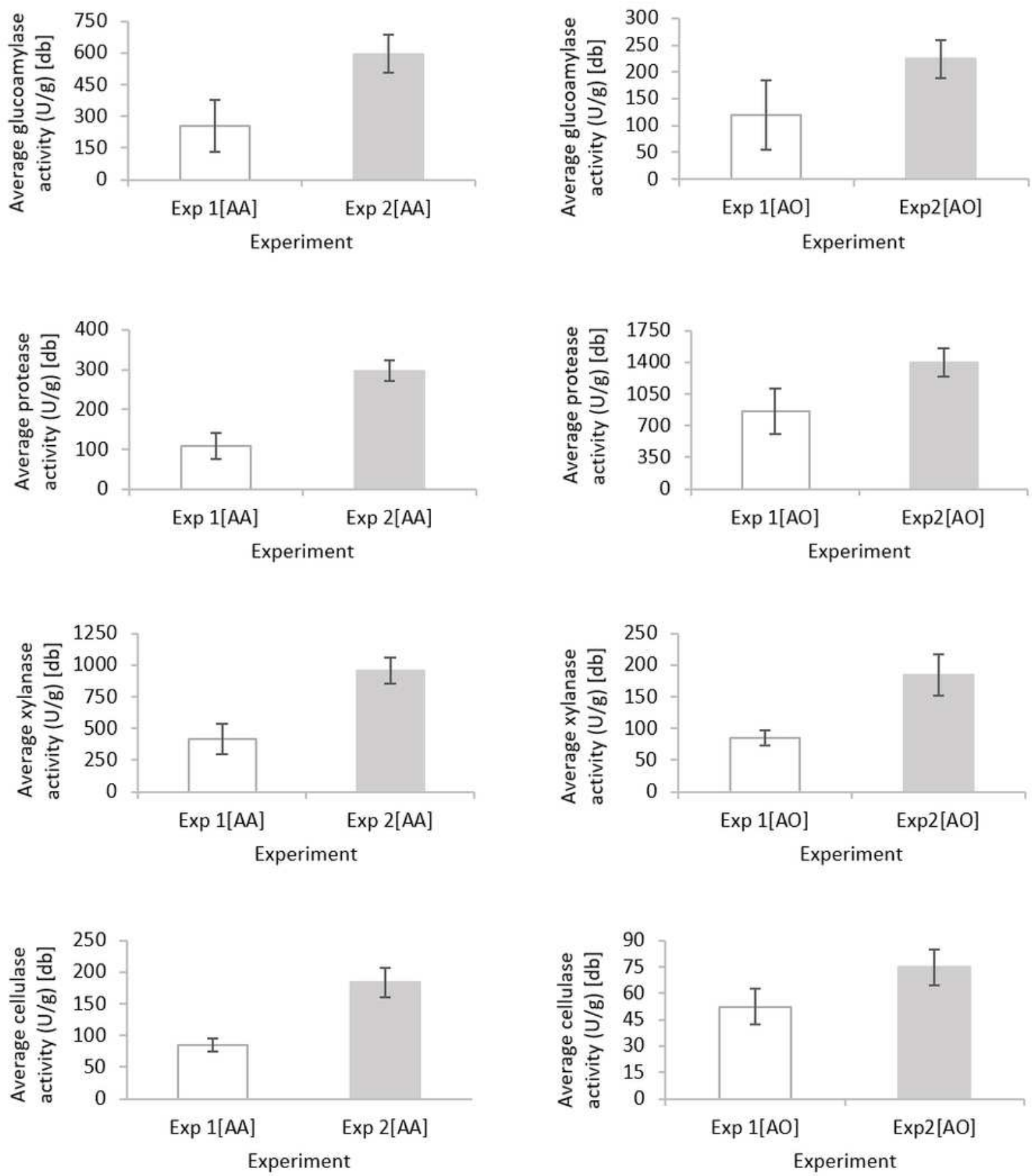

\section{Figure 11}

Fermentation summary of average enzymes production from multi-layer tray SSB with two air arrangements. [AA] - A. awamori and [AO] - A. oryzae. The results are shown as an average from eight trays and mean \pm standard deviation

\section{Supplementary Files}


This is a list of supplementary files associated with this preprint. Click to download.

- Figurecaption.docx 